

\section{Maximizing Residential Energy Savings: Net Zero Energy Home Technology Pathways}

Technical Report NREL/TP-550-44547

November 2008

\section{R. Anderson and D. Roberts}

Prepared under Task No. BET98001

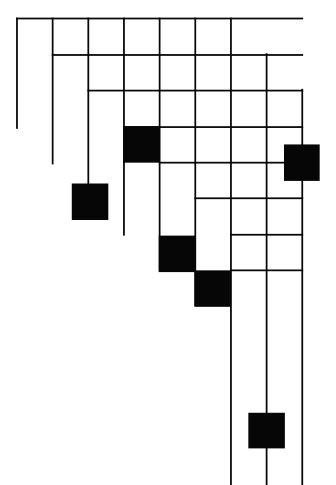

National Renewable Energy Laboratory 1617 Cole Boulevard, Golden, Colorado 80401-3393 303-275-3000 • www.nrel.gov

NREL is a national laboratory of the U.S. Department of Energy Office of Energy Efficiency and Renewable Energy

Operated by the Alliance for Sustainable Energy, LLC

Contract No. DE-AC36-08-GO28308 


\section{NOTICE}

This report was prepared as an account of work sponsored by an agency of the United States government. Neither the United States government nor any agency thereof, nor any of their employees, makes any warranty, express or implied, or assumes any legal liability or responsibility for the accuracy, completeness, or usefulness of any information, apparatus, product, or process disclosed, or represents that its use would not infringe privately owned rights. Reference herein to any specific commercial product, process, or service by trade name, trademark, manufacturer, or otherwise does not necessarily constitute or imply its endorsement, recommendation, or favoring by the United States government or any agency thereof. The views and opinions of authors expressed herein do not necessarily state or reflect those of the United States government or any agency thereof.

Available electronically at http://www.osti.gov/bridge

Available for a processing fee to U.S. Department of Energy and its contractors, in paper, from:

U.S. Department of Energy

Office of Scientific and Technical Information

P.O. Box 62

Oak Ridge, TN 37831-0062

phone: 865.576 .8401

fax: 865.576 .5728

email: mailto:reports@adonis.osti.gov

Available for sale to the public, in paper, from:

U.S. Department of Commerce

National Technical Information Service

5285 Port Royal Road

Springfield, VA 22161

phone: 800.553.6847

fax: 703.605.6900

email: orders@ntis.fedworld.gov

online ordering: http://www.ntis.gov/ordering.htm 


\section{Executive Summary}

To meet current U.S. Department of Energy zero-energy home (ZEH) performance goals, new technologies and solutions must increase whole-house efficiency savings by an additional $40 \%$ relative to those provided by best available components and systems. An expanded research program is needed to develop the key ZEH technologies and systems to fill this performance gap.

This report identifies a range of technology options to fill the residential efficiency gap in two categories:

- Improved systems based on modifications of existing products

- High-risk advanced system concepts.

Three sequential levels of market maturity and risk reduction must be accomplished before a new ZEH technology can be successfully used by builders, contractors, and homeowners:

1. Level 1 Risk Reduction - The technology must meet minimum builder, contractor, and homeowner performance and reliability requirements to be used in new and existing homes.

2. Level 2 Risk Reduction - The design, construction, and commissioning details for integrating the new technology into homes must be understood and validated.

3. Level 3 Risk Reduction - The field training, quality assurance/quality control, commissioning, and operations and maintenance requirements for the technology must be integrated as part of a production construction process to ensure that potential savings and benefits are achieved when the technologies are broadly implemented.

Ignoring these risk reduction requirements can significantly increase costs, homeowner complaints, and building or component failures and reduce near- and long-term energy savings.

At least $\$ 4$ million per year is needed for research on low- to medium-risk ZEH systems and $\$ 8$ million per year for research on high risk ZEH systems to achieve current U.S. Department of Energy ZEH performance goals. This estimate is based on the assumption that 10 projects per year will be supported in each risk category, with an average annual cost of $\$ 400 \mathrm{~K} /$ year for each low- to medium-risk project and an average annual cost of $\$ 800 \mathrm{~K} /$ year for each high-risk project. Based on research progress, the initial set of technology opportunities presented in this report will be downselected over time to focus on the subset of projects and solutions that are expected to provide the greatest overall cost and performance benefits. The final development of ZEH systems for Building America research homes from this expanded research program is required by 2015 to achieve the Department's net ZEH goal by 2020. 


\section{Acronyms}

$\begin{array}{ll}\text { A/C } & \text { air conditioning } \\ \text { AFUE } & \text { annual fuel utilization efficiency } \\ \text { CFL } & \text { compact fluorescent lamp } \\ \text { dc } & \text { direct current } \\ \text { DHW } & \text { domestic hot water } \\ \text { EER } & \text { energy efficiency ratio } \\ \text { EF } & \text { emissions factor } \\ \text { HSPF } & \text { heating season performance factor } \\ \text { HVAC } & \text { heating, ventilation, and air conditioning } \\ \text { MEL } & \text { miscellaneous electrical load } \\ \text { O\&M } & \text { operations and maintenance } \\ \text { PV } & \text { photovoltaic } \\ \text { SDHW } & \text { solar domestic hot water } \\ \text { SEER } & \text { Seasonal Energy Efficiency Ratio } \\ \text { SHGC } & \text { solar heat gain coefficient } \\ \text { SLA } & \text { specific leakage area } \\ \text { VHP } & \text { very high-performance } \\ \text { ZEH } & \text { zero-energy home }\end{array}$




\section{Contents}

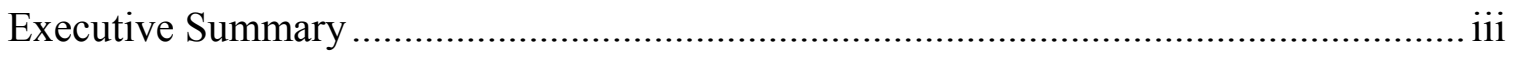

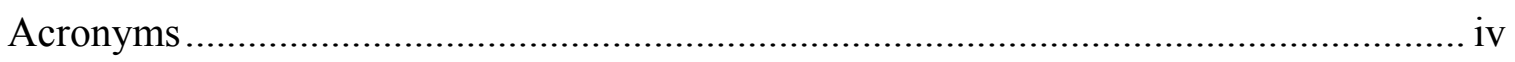

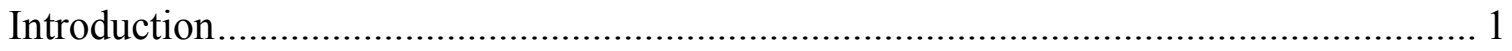

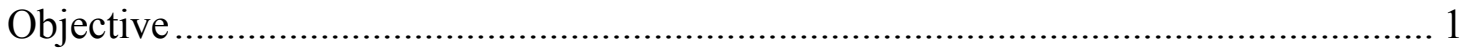

Critical Zero-Energy Home Performance Gaps...................................................... 1

Zero-Energy Home Technology Barriers and Risk Reduction Requirements................... 3

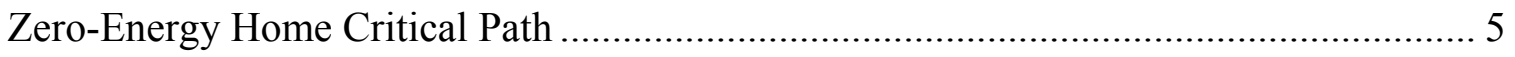

Overview of Key Zero-Energy Home Technology Pathways ........................................ 6

Multi-Year Zero-Energy Home Research Plan...................................................... 15

Recommended Criteria for Selecting Projects for Expanded Zero-Energy Home

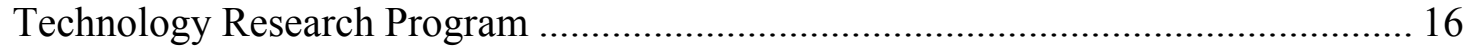

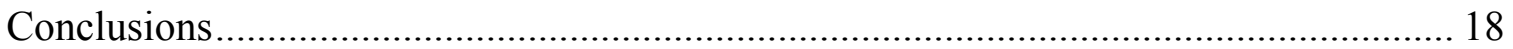

Appendix A - Reference Technology Packages for 50\% Homes ............................... 19

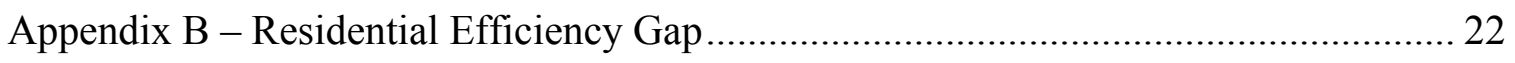

Appendix C - Overview of Zero-Energy Home Technology Energy Saving Goals........ 28

Appendix D - Source Energy End-Use Consumption in 50\% Reference Homes............ 31

Appendix E - Climate Sensitivity of Zero-Energy Home Pathways ............................... 34

Appendix F - Impact of Energy Cost on Consumer Adoption of Zero-Energy Home

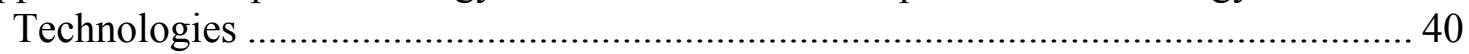




\section{Introduction \\ Objective}

Significant increases in residential energy efficiency are required to meet emerging global and U.S. energy efficiency goals. The objective of this report is to provide an overview of the key residential efficiency technology opportunities and barriers that must be addressed to successfully develop cost-neutral net zero-energy homes (ZEHs). New technologies and systems must increase whole-house energy savings by an additional $40 \%$ relative to those that can be currently provided by best available residential components and systems.

\section{Critical Zero-Energy Home Performance Gaps}

Critical ZEH performance gaps ${ }^{1,2,3}$ are defined in terms of the incremental source energy savings and incremental costs that must be achieved by new systems to successfully compete with current best available system solutions. New systems must provide significant cost and performance benefits relative to available systems to fill the energy savings gaps that currently limit the achievement of net ZEHs. For ZEHs to expand beyond high-value niche markets and achieve broad market acceptance, the total amortized annual incremental cost of the engineered energy technology package for a $\mathrm{ZEH}$ must be comparable to the annual utility bill savings that are provided by a ZEH (see Figure 1).

New residential system solutions that provide an additional $40 \%$ in whole-house efficiency savings (relative to the $50 \%$ homes currently being developed by the program $)^{4}$ must be developed between 2009 and 2015 in order to achieve net ZEHs by 2020. The following systems represent a minimum ${ }^{5}$ set of efficiency improvements required to achieve cost-effective net ZEHs:

- High-R Wall Systems - Durable high-R wall systems for cold, northern marine, and mixed climates, leading to development of an R-30+ wall assembly with an incremental cost of $\$ 2 / \mathrm{ft}^{2}$ floor area relative to an $\mathrm{R}-192 \times 6$ wall.

- Cold Climate Domestic Hot Water (DHW) - DHW system with \$2000 incremental system cost and $30 \%$ reduction in annual energy use relative to a gas tankless hot water system with efficiency factor $(\mathrm{EF})=0.8$.

- Cold Climate R-10 Window Assembly - R-10 window assembly with a minimum solar heat gain coefficient (SHGC) of 0.3 and a cost of $\$ 20 / \mathrm{ft}^{2}$ (incremental cost of $\$ 4 / \mathrm{ft}^{2}$ relative to current low-e windows).

\footnotetext{
${ }^{1}$ FY 2009 Residential AOP Evaluation Criteria, 3/30/2008.

${ }^{2}$ Critical Building America Technology Targets and Example Gate 1A Technology Packages, 3/30/2008.

${ }^{3}$ Cost performance targets were established using BEopt default cost data, assuming future PV costs of $\$ 3.30 / \mathrm{W}$. Analysis was done for a west-facing $2500-\mathrm{ft}^{2}$ house with $18 \%$ window area. "Neutral cost" means that a homeowner moving from a 1990s house into a new home will have the same energy-related costs (utility bills plus financing costs for energy upgrades) as they had in their old house (utility bills only). Incremental home costs were evaluated relative to IECC 2003.

${ }^{4}$ Examples of the technologies that will be used to achieve Building America 50\% homes are included in Appendix A.

${ }^{5}$ This is a minimum set because only space conditioning, hot water, and miscellaneous electrical loads (MELs) have been targeted. An additional 3\%-5\% of savings will be contributed by solid-state lighting as light-emitting diode price points and performance continue to improve.
} 
- Very High Performance (VHP) A/C System ${ }^{6}$ - A VHP A/C system with $30 \%$ reduction in annual energy use and an incremental cost of $\$ 1000$ relative to a current Seasonal Energy Efficiency Ratio (SEER) 18/energy efficiency ratio (EER) 13.4 twospeed system with tight ducts in conditioned space.

- MEL Reduction - 30\% reduction in miscellaneous electrical energy use with an incremental cost of $\$ 1000$.

High-performance homes that meet these specifications can also be easily operated to minimize energy use during periods of peak utility electric demand, resulting in reduced peak loads and increased grid stability. ${ }^{7,8}$

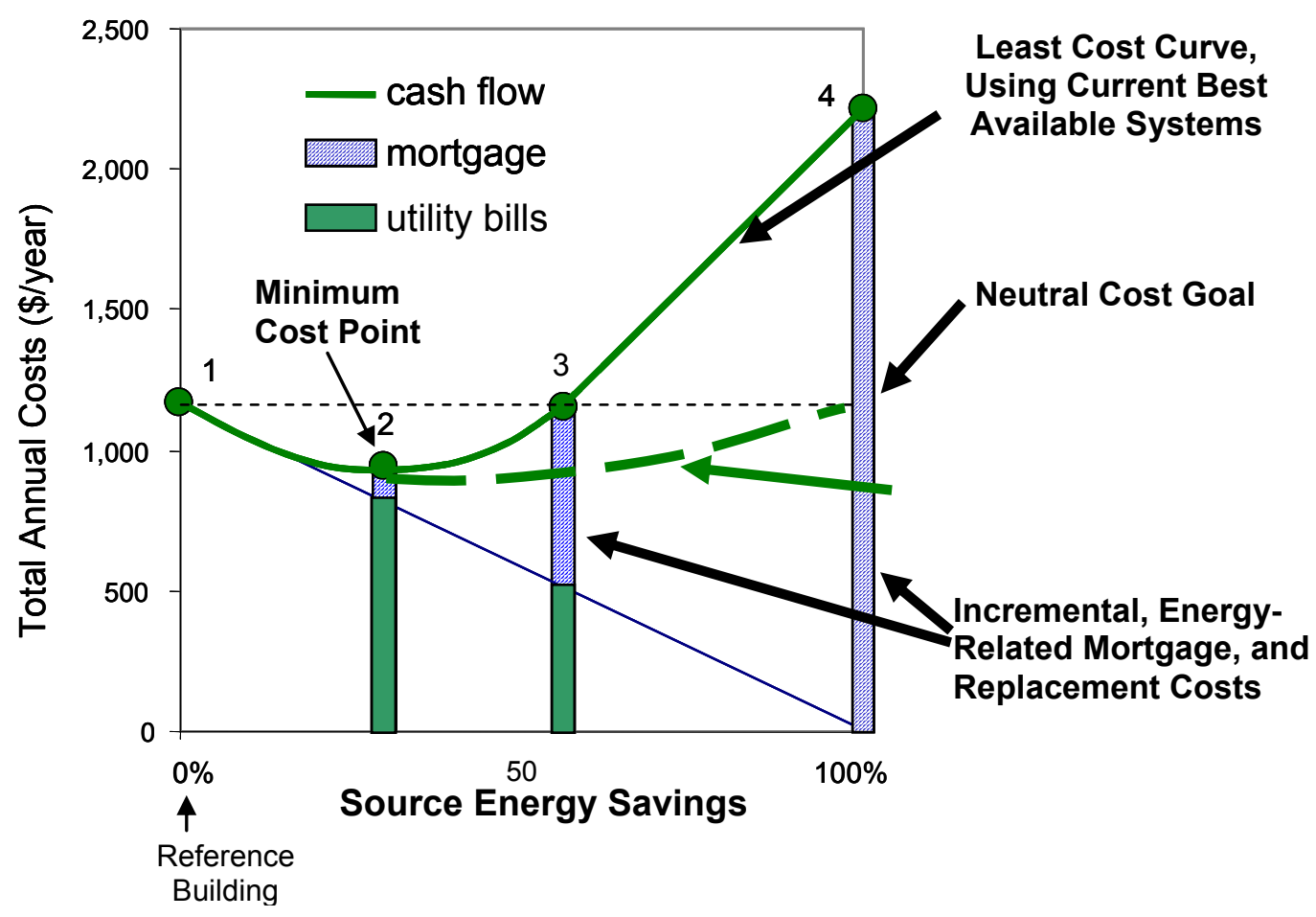

Figure 1. ZEH Whole-House Cost/Performance Target

\footnotetext{
${ }^{6}$ The VHP A/C performance goal is an overall system performance goal and includes savings from efficiency (improvements in coefficient of performance [COP]), zoning, night cooling, evaporative cooling, heat recovery, and capacity modulation.

${ }^{7}$ Anderson, R.; Christensen, C.; Horowitz, S. "Program Design Analysis Using BEopt Building Energy Optimization Software: Defining a Technology Pathway Leading to New Homes with Zero Peak Cooling Demand." In proceedings 2006 ACEEE Summer Study on Energy Efficiency in Buildings: Less Is MoreEn Route to Zero Energy Buildings, August 2006.

${ }^{8}$ Anderson, R., Hammon. R., Keesee, M. "Maximizing the Benefits of Zero Energy Homes." Home Energy Magazine Special Edition on Solar and Efficiency: Meeting the Energy Needs of the $21{ }^{\text {st }}$ Century, March 2006.
} 


\section{Zero-Energy Home Technology Barriers and Risk Reduction Requirements}

Homeowners, homebuilders, and contractors tend to avoid technologies that

- Increase risks

- Increase overall costs

- Have the potential to cause customer complaints

- Require additional training or oversight of subcontractors

- Require use of new and unfamiliar suppliers, materials, or equipment

- Require additional planning steps or code approvals

- Have the potential to increase future home warranty and callback costs.

Builders, in their role as residential system integrators, are often viewed as being risk averse with respect to adoption of new technologies. However, long-term trends in building construction practices do not support this conclusion. For example, builders' use of premanufactured framing components and panelized wall systems is expected to nearly double by 2010 compared to 1990 levels. ${ }^{9}$ It is more accurate to say that builders tend to avoid risky technologies that do not have a high likelihood of delivering proven benefits.

As builders and contractors respond to increased consumer and policy-driven demand for energy-efficient and sustainable homes, they need credible information to decide if they can successfully use a broad range of new products and systems with unknown risks and unproven benefits. The U.S. Department of Energy Building Technologies Program is the only national research program that is currently developing this information.

In addition to achieving ZEH energy efficiency objectives, three levels of risk reduction must be achieved before a new technology can be successfully used by builders, contractors, and homeowners:

- Level 1 Risk Reduction - The technology must meet minimum builder, contractor, and homeowner performance and reliability requirements for use in new and existing homes.

- Level 2 Risk Reduction - The design, construction, and commissioning details for integrating the new technology into homes must be well understood and validated.

- Level 3 Risk Reduction - The field training, construction, and installation quality assurance/quality control, commissioning, and operations and maintenance (O\&M) procedures for the technology must be successfully applied as integral parts of the construction process to ensure that potential savings and benefits are achieved when the technologies are broadly implemented.

\footnotetext{
${ }^{9}$ Shuler, A. "The Factory Built Components Industry Is Almost as Large as the Softwood Lumber Industry.” Structural Building Components Magazine, April 2003.
} 
Ignoring these risk reduction requirements significantly increases costs, homeowner complaints, and building failures, and reduces chances of achieving near- and long-term energy savings. These three levels of residential technology maturity are summarized in more detail in Figure 2.

1. Meets minimum residential performance requirements. Technology meets minimum cost, reliability, O\&M, and durability requirements and provides high potential value to builders, contractors, and homeowners.

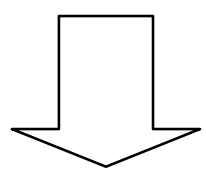

2. Can be integrated with the residential construction process. Builders, contractors, and code officials understand best practice design details, commissioning, construction sequencing, costs, and benefits.

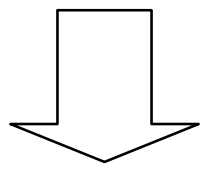

3. Can be implemented on a production basis. Suppliers, builders, and contractors understand and accept responsibility for quality assurance, quality control, training, and commissioning.

Figure 2. The Three Levels of Risk Reduction That Must Be Achieved by Technologies and Systems Developed for Use in ZEHs

The first level of risk reduction must be reached before the technology can be included in initial pilot projects with builders. The second level of risk reduction must be reached before innovative builders of high-performance homes can evaluate overall costs, benefits, and house redesign requirements. The third level of risk reduction must be reached before broad use can be achieved with mainstream production builders. 


\section{Zero-Energy Home Critical Path}

Multiple approaches must be explored during the initial stages of research on $\mathrm{ZEH}$ technologies and systems to ensure a robust solution set that meets residential market risk reduction requirements. In addition, because of the lead time required to move from Level 1 to Level 3 maturity, ZEH technology solutions with Level 1 maturity must be developed by 2015 in order to achieve cost-effective whole-house Level 3 ZEH system solutions by 2020 .

\begin{tabular}{|c|c|c|c|c|}
\hline \multirow[b]{2}{*}{$\begin{array}{l}\text { G3: } 50 \% \text { Whole-House Savings } \\
\text { Level: Current best available } \\
\text { equipment integrated with a ZEH } \\
\text { envelope. }\end{array}$} & 2009 & 2015 & 2018 & 2020 \\
\hline & & & \multicolumn{2}{|c|}{$\begin{array}{l}\text { G3 ZEH-Ready } \\
\text { Envelope }\end{array}$} \\
\hline $\begin{array}{l}\text { G1: } 70 \% \text { Savings Level: } \\
\text { Expanded ZEH technology } \\
\text { research program required to } \\
\text { develop ZEH systems by } 2015 \text {. }\end{array}$ & & & & \\
\hline G2: ZEH Prototype Houses & & & & \\
\hline $\begin{array}{l}\text { G3: Neutral Cost ZEH } \\
\text { Communities }\end{array}$ & & & & \\
\hline
\end{tabular}

Figure 3. ZEH Critical System Research Path (G1 = passes Level 1 risk reduction requirement, $\mathbf{G} 2$ = passes Level 2 risk reduction requirement, $\mathbf{G} 3$ = passes Level 3 risk reduction requirement)

The ZEH critical research path focuses on the development of ZEH-ready envelopes ${ }^{10}$ combined with current best available equipment to achieve $50 \%$ homes by 2015 . Initial production of advanced ZEH equipment and systems that provide an additional $40 \%$ in energy savings relative to a $50 \%$ home are also required by 2015 to achieve ZEHs by 2020. An expanded ZEH technology research program is needed to target ZEH technology opportunities that have a high potential for reaching Level 1 maturity within the next six years. The set of technology opportunities that are investigated will be downselected over time to focus on the subset of projects and solutions that have been demonstrated to provide the highest overall cost and performance benefits relative to multi-year ZEH cost and performance goals.

\footnotetext{
${ }^{10}$ For an excellent review of the history of development of high-R envelopes, see Lstiburek, J., "Building America.” ASHRAE Journal, December 2008, pp 60-65.
} 


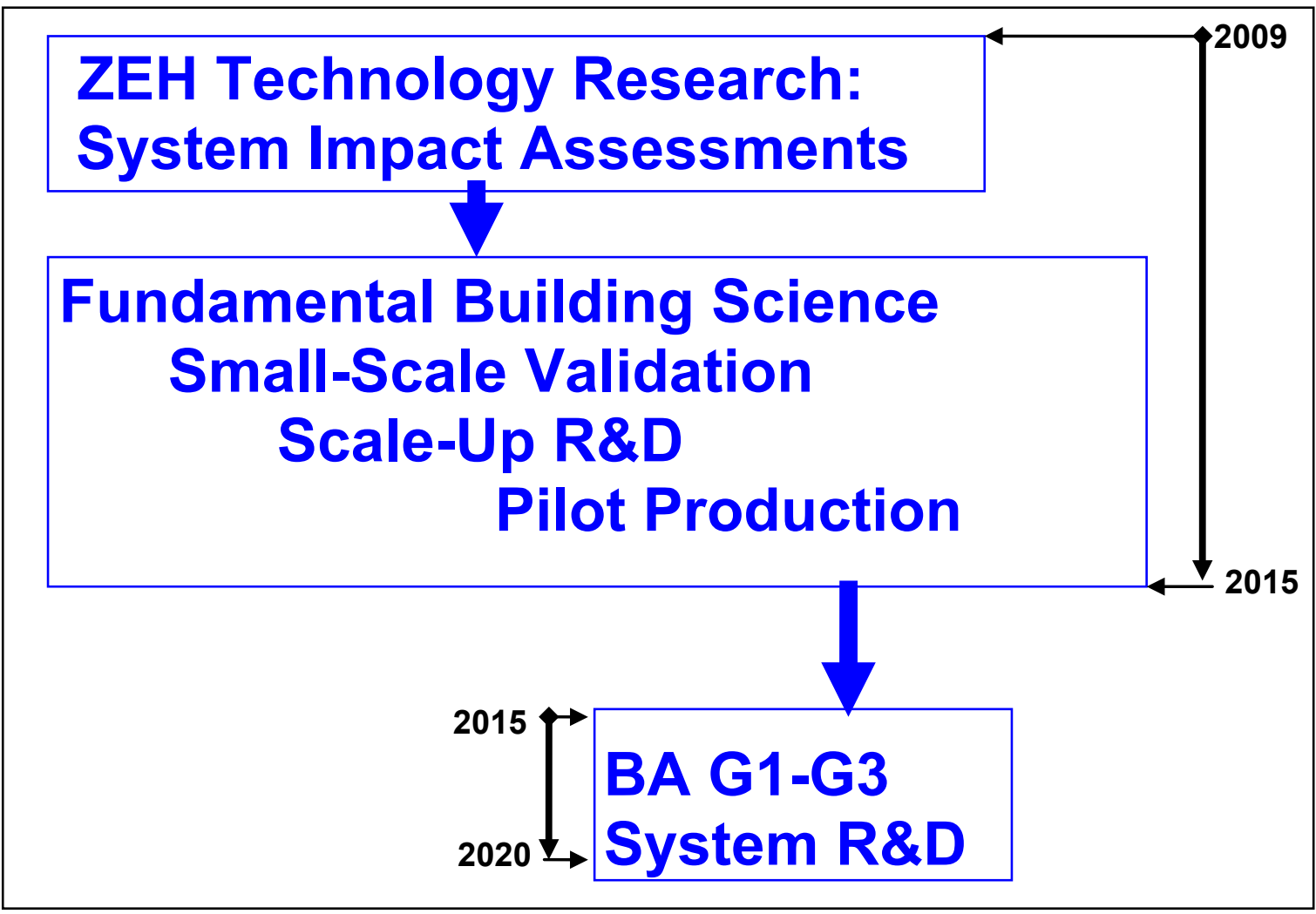

Figure 4. Linkage Between Expanded ZEH Technology Research and Building America Whole-House ZEH System Research

\section{Overview of Key Zero-Energy Home Technology Pathways}

The residential research program is evaluating the potential impacts of a broad range of technology options to determine their expected incremental, whole-building cost and performance benefits compared to system solutions for high-performance homes that achieve 50\% in source energy savings relative to the Building America Benchmark. ${ }^{11}$ Options that appear to provide the highest marginal benefits (highest incremental energy savings at least incremental cost) will be recommended for further study. The system performance impact assessments will be updated as additional research results are developed from initial proof-of-concept studies and developmental research efforts (see Figure 4).

The ZEH technology opportunities discussed in this report are grouped into six major system categories: Energy Storage Systems; Envelope Systems; Hot Water Systems; Lighting, Appliance, and Miscellaneous Electric Systems; Space Conditioning/HVAC Systems; and Community Systems.

The technology opportunities are prioritized within each system category according to the estimated chance of successfully achieving ZEH system cost, performance, and risk reduction requirements by 2015 .

\footnotetext{
${ }^{11}$ Examples of the technology packages for $50 \%$ homes that are being used to determine incremental benefits are included in Appendix A.
} 
Modifications of current products are estimated to have a medium to high chance of success (low to medium risk) relative to their ability to achieve ZEH system performance requirements by 2015. Depending on the level of R\&D investments, advanced concepts are expected to have a more difficult time achieving ZEH reliability and performance requirements by 2015 (higher risk).

Updates to system impact assessments and/or additional exploratory research should be considered in cases where specific opportunities for improving system benefits have been identified. As more detailed performance information is developed, impact assessments will be based on full performance maps that are implemented as technology options within the BEopt ${ }^{12,13,14,15}$ analysis software. In cases where full performance maps are not available, simplifying assumptions may be used to provide initial impact assessments. ${ }^{16}$

- Characteristics of Priority 1 Technology Opportunities - Technologies in this group are based on modifications of current products to meet $\mathrm{ZEH}$ cost and performance requirements and are given the highest priority because they are expected to have the lowest overall risk of failure, highest chance of resulting in significant cost sharing from industry partners, and lowest time to market.

- Characteristics of Priority 2 Technology Opportunities - Technologies in this group are based on advanced concepts rather than on modifications of existing products and are estimated to have higher risk of failure than Priority 1 technologies. They are also expected to be less likely to attract large investments from industry partners.

The overall results of the ZEH risk and benefit evaluation are summarized in Figure 5 and in Table 1 through Table 6. In these tables, the options within each risk level that are expected to have the highest system benefits are indicated in bold type. Options that may have promise but need additional development and evaluation to determine incremental system benefits are underlined. Options that are currently expected to have low incremental system benefits are italicized.

\footnotetext{
${ }^{12}$ Anderson, R.; Christensen, C.; Horowitz, S. "Analysis of Residential Systems Targeting Least-Cost Solutions Leading to Net Zero Energy Homes," ASHRAE Transactions, 2006.

${ }^{13}$ Anderson, R. "Determining Technology Options and Performance Goals for Future SMUD Residential Energy Programs Using Advanced Energy Efficiency Measure Screening and Evaluation Tools." SMUD, July 2006.

${ }^{14}$ Christensen, C.; Anderson, R.; Horowitz, S.; Courtney, A.; Spencer, J. BEopt(TM) Software for Building Energy Optimization: Features and Capabilities. 21 pp.; NREL Report No. TP-550-39929, 2006.

${ }^{15}$ Horowitz, S.; Christensen, C.; Brandemuehl, M.; Krarti, M. Enhanced Sequential Search Methodology for Identifying Cost-Optimal Building Pathways. NREL Report No. CP-550-43238, 2008.

${ }^{16}$ Note: The NREL analysis team is interested in adding performance data for options included in this report and including additional options that may have been inadvertently omitted from this report. Please e-mail information to: Ren_Anderson@nrel.gov.
} 


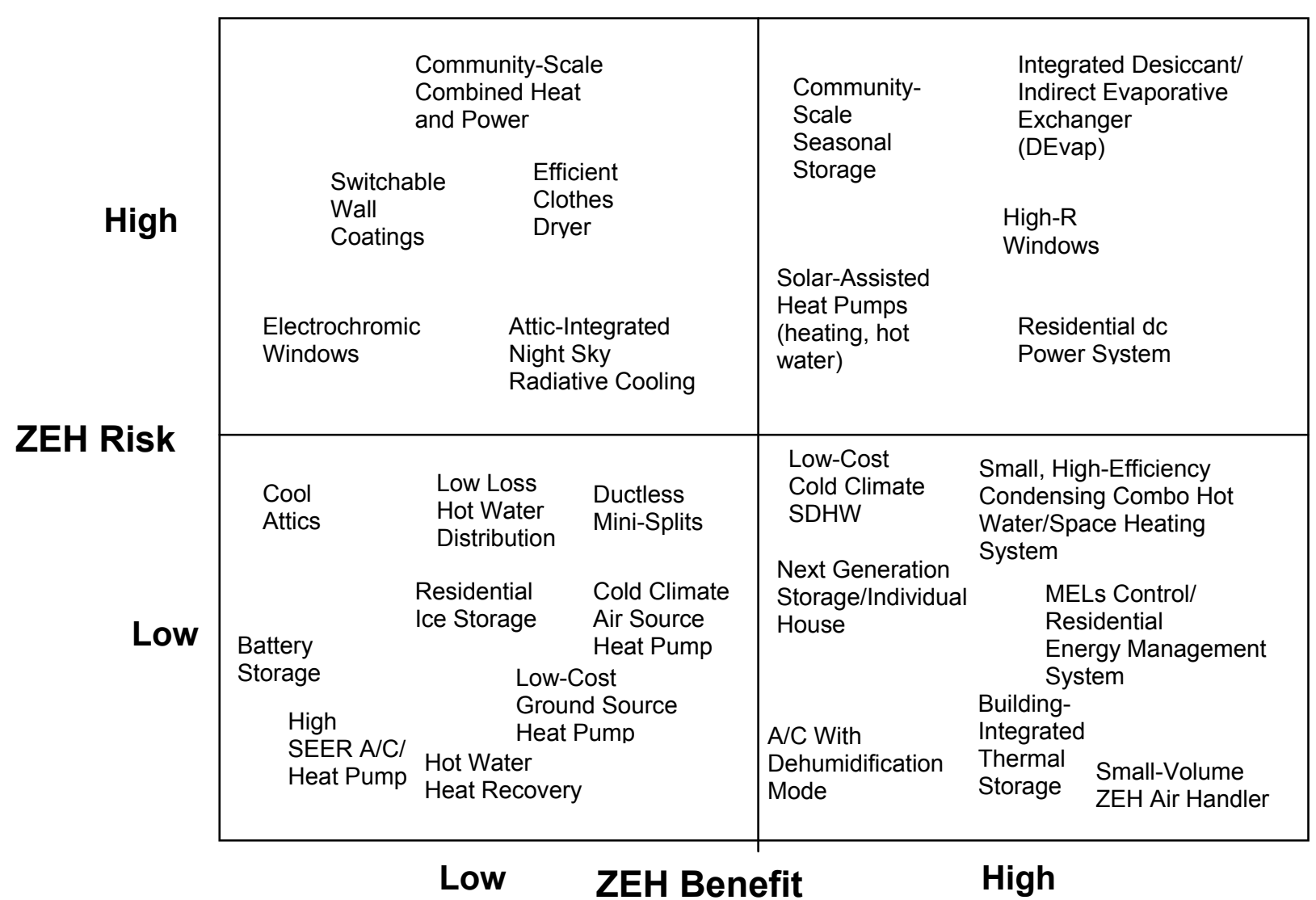

Figure 5. Overview of Option Risks and Benefits Relative to ZEH Technology Gaps 
Table 1. Category 1 - ZEH Energy Storage Systems

\begin{tabular}{|c|c|}
\hline \multicolumn{2}{|c|}{$\begin{array}{l}\text { Opportunity/Need: } \\
\text { - Short-term thermal storage (4-6 hours) is needed to reduce afternoon peak electric } \\
\text { demand. } \\
\text { - Diurnal storage is needed to use winter solar gains to meet nighttime heating loads and } \\
\text { to shift summer daytime cooling loads to night ventilation cooling. } \\
\text { - Seasonal storage is needed to use excess summer solar thermal energy to offset winter } \\
\text { heating loads. }\end{array}$} \\
\hline \multicolumn{2}{|c|}{$\begin{array}{l}\text { Overall Risks: } \\
\text { - Sensible energy storage materials are more expensive than lightweight construction } \\
\text { materials. } \\
\text { - Phase change materials and thermochemical storage materials are expensive, difficult to } \\
\text { contain, and may increase chemical exposure and smoke and fire hazards. }\end{array}$} \\
\hline \multicolumn{2}{|l|}{$\begin{array}{l}\text { Cost/Performance Goal: } \\
\text { TBD }\end{array}$} \\
\hline $\begin{array}{l}\text { Priority 1: Modifications of Exi } \\
\text { Systems (Low to Medium Risk }\end{array}$ & d Systems (High Risk) \\
\hline $\begin{array}{l}\text { Building-integrated thermal storage (4-8 ton } \\
\text { hours) for homes with very high } \\
\text { performance envelopes. Maximize use of } \\
\text { existing sensible storage by locating } \\
\text { insulation outside the structure of the } \\
\text { building. }\end{array}$ & $\begin{array}{l}\text { Desiccant-based thermal storage for } \\
\text { simultaneous increased energy density of heat } \\
\text { storage and cooling storage on single-home } \\
\text { Scale. Super capacitor storage. Flywheel } \\
\text { storage. Super-efficient battery storage. Plug-in } \\
\text { electric or hybrid vehicles with controls to allow } \\
\text { user to optimize overall energy use and cost } \\
\text { benefits of vehicle battery storage. }\end{array}$ \\
\hline
\end{tabular}


Table 2. Category 2 - ZEH Envelope Systems

\begin{tabular}{|c|c|}
\hline $\begin{array}{l}\text { Opportunity/Need: } \\
\text { Envelope systems are difficult and expensive to rep } \\
\text { design decisions are felt for } 50-100 \text { years. Current } \\
\text { insulation levels based on homeowner energy costs }\end{array}$ & $\begin{array}{l}\text { after initial construction. The impacts of initial } \\
\text { energy codes do not target the most cost-effective } \\
\text { financial risks. }\end{array}$ \\
\hline $\begin{array}{l}\text { Overall Risks: } \\
\text { Increased levels of insulation also increase wall thick } \\
\text { installation, trim, siding installation, door installations }\end{array}$ & $\begin{array}{l}\text { s and require new design details for window } \\
\text { por retarders, air barriers, and drainage planes. }\end{array}$ \\
\hline $\begin{array}{l}\text { Overall Cost/Performance Goals: } \\
30 \% \text { reduction in the cooling and heating loads of a }\end{array}$ & $\%$ reference house at an incremental cost of $\$ 5000$. \\
\hline $\begin{array}{l}\text { Priority 1: Modifications of Existing Systems } \\
\text { (Low to Medium Risk)* }^{*}\end{array}$ & Priority 2: Advanced Systems (High Risk)* \\
\hline $\begin{array}{l}\text { R-7 to R-10 window systems (whole window R- } \\
\text { value including insulating glass unit, edge seals, } \\
\text { and frame) }\end{array}$ & $\begin{array}{l}\text { Durable, dynamic external solar shading, wall and } \\
\text { roof venting, and radiant insulation systems. Smart } \\
\text { building materials and components that meet } \\
\text { residential durability and reliability requirements } \\
\text { (variable } R \text {, variable emissivity, variable absorptivity, } \\
\text { variable permeability, variable transmissivity, } \\
\text { variable reflectivity) } \\
\text { Thin, high } R \text {-value insulation materials that eliminate } \\
\text { thermal bridges in wall framing and fastening } \\
\text { systems (aerogel materials, etc.). }\end{array}$ \\
\hline $\begin{array}{l}\text { Very high } R(R-40+) \text { sealed attic insulation/roof } \\
\text { replacement retrofit strategies for existing } \\
\text { homes in hot/dry climates with } A / C \text { and ducts in } \\
\text { attic. }\end{array}$ & \\
\hline $\begin{array}{l}\text { Low-cost, easy-to-install raised heel roof truss } \\
\text { systems for high-R attic insulation systems, } \\
\text { optimized approach using high- or low-density } \\
\text { perimeter foam plus blow-in fiber insulation. } \\
\text { Fast, perimeter air sealing techniques for new } \\
\text { and retrofit applications: recyclable, easy to use } \\
\text { foam packs, etc. }\end{array}$ & \\
\hline $\begin{array}{l}\text { Durable, R-30+ wall systems (framing, vapor } \\
\text { retarder, insulation, drainage plane) rated as a } \\
\text { complete system, rather than a series of } \\
\text { components. Needs to address thermal, } \\
\text { moisture, air, structural, and bugs. Insulating } \\
\text { wall sheathing that eliminates need to use } \\
\text { oriented strand board for structural purposes } \\
\text { (structural external insulating sheathing). } \\
\text { Efficient siding attachment systems for use with } \\
\text { thick insulating sheathing. Low-cost structural } \\
\text { insulated panels. }{ }^{18}\end{array}$ & \\
\hline
\end{tabular}

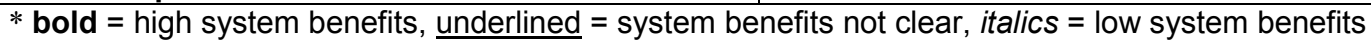

\footnotetext{
${ }^{17} \mathrm{R} 10$ window assembly with a minimum SHGC of 0.3 and cost of $\$ 20 / \mathrm{ft}^{2}$ (incremental cost of $\$ 4 / \mathrm{ft}^{2}$ relative to current low-e windows).

${ }^{18}$ Durable high $\mathrm{R}$ wall systems for cold, northern marine, and mixed climates, leading to development of an $\mathrm{R}-30+$ whole wall assembly with an incremental cost of $\$ 2 / \mathrm{ft}^{2}$-floor area relative to an R-19 $2 \times 6$ wall.
} 
Table 3. Category 3 - ZEH Hot Water Systems

\begin{tabular}{|c|c|}
\hline $\begin{array}{l}\text { Opportunity/Need: } \\
\text { Current best available hot water systems are a } \\
\text { about } 1.5-2 \text { (heat pump water heaters). Integr } \\
\text { energy savings. }\end{array}$ & $\begin{array}{l}70 \%-90 \% \text { efficient (gas) or have COPs of } \\
\text { with renewable energy sources can increase }\end{array}$ \\
\hline $\begin{array}{l}\text { Overall Risks: } \\
\text { Hot water energy usage patterns vary dramatica } \\
\text { users will not benefit from expensive systems. } \\
\text { operate correctly, reducing delivered savings. R } \\
\text { future performance of solar hot water systems. }\end{array}$ & $\begin{array}{l}\text { from one household to another. Low hot water } \\
\text { plicated systems are difficult to install and } \\
\text { of shading from mature trees may reduce }\end{array}$ \\
\hline $\begin{array}{l}\text { Overall Cost/Performance Goal: } \\
30 \% \text { reduction in annual hot water energy used } \\
\text { of } \$ 2000 \text {. }\end{array}$ & $50 \%$ reference house at an incremental cost \\
\hline $\begin{array}{l}\text { Priority 1: Modifications of Existing } \\
\text { Systems (Low to Medium Risk)* }\end{array}$ & Priority 2: Advanced Systems (High Risk)* \\
\hline $\begin{array}{l}\text { High-performance condensing hot water } \\
\text { heating systems with integrated solar } \\
\text { storage, hydronic heating and EF 0.95+ } \\
\text { when used in space heating mode. }\end{array}$ & $\begin{array}{l}\frac{\text { Low-lift } \mathrm{CO}_{2}}{2.0+, 130^{\circ}-}-\frac{\text { heat pump water heater, } \mathrm{COP}}{150^{\circ} \mathrm{F} \text { delivery temperature, for }} \\
\text { combined hot water and space heating } \\
\text { applications. }\end{array}$ \\
\hline $\begin{array}{l}\text { Simple, low-cost, standardized, combined } \\
\text { solar hot water ( } 70 \% \text { solar fraction) and } \\
\text { space heating ( } 30 \% \text { solar fraction) systems } \\
\text { for cold climates. Gas tankless, gas } \\
\text { tankless/electric hybrid, or super-efficient } \\
\text { small tank gas DHW systems that work well } \\
\text { with solar pre-heat systems. }\end{array}$ & $\begin{array}{l}\text { Solar-assisted heat pumps for hot water } \\
\text { applications with variable lift control to optimize } \\
\text { performance over a broad range of input } \\
\text { temperatures. }\end{array}$ \\
\hline $\begin{array}{l}\text { Low-loss hot water distribution systems with } \\
\text { occupancy based control to minimize stranded } \\
\text { energy losses. Efficient, low-cost waste water } \\
\text { heat recovery systems. }\end{array}$ & \\
\hline
\end{tabular}

* bold = high system benefits, $\underline{\text { underlined }}=$ system benefits not clear, italics = low system benefits 
Table 4. Category 4 - ZEH Lighting, Appliances, and Miscellaneous Electrical Systems

Opportunity/Need:

Significant amounts of electricity are used in standby modes for home office, home entertainment, lighting, and appliances. Advanced controls, combined with occupant feedback, can provide significant energy savings. Home controls are an emerging feature of utility smart grid and demand-response programs. Research on efficient lighting sources is not included within the scope of expanded research on ZEH technologies because the solid-state lighting program is already addressing this area.

Overall Risks:

Current wired control systems are prohibitively expensive. Occupants will not use control systems that are difficult to program. Savings will be highly variable depending on occupant behavior, climate, and usage profiles. The numerous appliances and miscellaneous electricity uses make it difficult to achieve uniform levels of energy savings across all end uses.

\section{Overall Cost/Performance Goal:}

$20 \%$ reduction in the combined annual electrical energy used by a $50 \%$ reference house for lighting, appliances, and miscellaneous electrical uses at an incremental cost of \$2000.

Priority 1: Modifications of Existing Systems (Low to Medium Risk)*

Low-cost, whole-house, occupancy-based energy control systems with integrated Tstat, ventilation, lighting, home office, peak electric demand, home entertainment control, whole house sleep mode, and low standby power requirements (self-powered wireless) with standardized dashboard allowing for centralized viewing and control of all electricity usage (e.g. lighting, appliances) with the ability to program appliance usage (daily, weekly, monthly, vacation). ${ }^{19}$

Priority 2: Advanced Systems (High Risk) ${ }^{\star}$

Improved occupancy sensors (reducing false positives and negatives) for plug, HVAC zoning, and lighting control.

Efficient direct dc power systems for HVAC, home entertainment and home office equipment. Including standardized lowvoltage protocol and wiring system with central efficient rectification for dc electronics and lighting as well as battery recharging applications.

Efficient clothes dryers. Closed-cycle, unvented desiccant-based, condensing, or heat pump clothes dryer.

Efficient, smart grid-capable appliances and HVAC equipment with integrated diagnostics and energy control modes.

* bold $=$ high system benefits, $\underline{\text { underlined }}=$ system benefits not clear, italics $=$ low system benefits

${ }^{19}$ A multi-year research plan has been developed for MELs. Initial work will begin in January 2009. The MEL goal is a 30\% reduction in miscellaneous electrical energy use with an incremental cost of $\$ 1000$. 
Table 5. Category 5 - ZEH Space Conditioning/HVAC Systems

\begin{tabular}{|c|c|}
\hline $\begin{array}{l}\text { Opportunity/Need: } \\
\text { Heating and cooling loads in ZEHs will be less than } \mathrm{h} \\
\text { of efficient, downsized systems with ducts located in } \\
\text { increase energy savings by reducing parasitic loads } \\
\text { night vent cooling, indirect evaporative cooling, and w }\end{array}$ & $\begin{array}{l}\text { If those in conventional homes and will allow the use } \\
\text { onditioned space. There are broad opportunities to } \\
\text { id developing hybrid cooling systems that integrate } \\
\text { ste heat recovery. }\end{array}$ \\
\hline $\begin{array}{l}\text { Overall Risks: } \\
\text { Reduced cooling loads in } \mathrm{ZEHs} \text { will reduce A/C opera } \\
\text { during the swing seasons in hot humid and mixed hur } \\
\text { maintenance requirements, provide reduced levels of } \\
\text { systems. }\end{array}$ & $\begin{array}{l}\text { ng hours and increase internal relative humidity } \\
\text { id climates. New systems may have increased } \\
\text { omfort, or have reduced reliability relative to current }\end{array}$ \\
\hline $\begin{array}{l}\text { Overall Cost/Performance Goal: } \\
\text { Very high performance (VHP) systems that use } 30 \% \\
\text { house. }\end{array}$ & s energy than the systems in a $50 \%$ reference \\
\hline $\begin{array}{l}\text { Priority 1: Modifications of Existing Systems } \\
\text { (Low to Medium Risk)* }^{*}\end{array}$ & Priority 2: Advanced Systems (High Risk)* \\
\hline $\begin{array}{l}\text { A/C with efficient dehumidification mode to limit } \\
\text { high interior relative humidity excursions when } \\
\text { space cooling is not required. }\end{array}$ & $\begin{array}{l}\text { Compact, integrated desiccant dehumidifier and } \\
\text { evaporative cooling heat and mass exchanger } \\
\text { driven by solar and waste heat (DEvap). }{ }^{20}\end{array}$ \\
\hline $\begin{array}{l}\text { Indirect evaporative coolers with integrated direct } \\
\text { exchange or desiccant backup for hot/dry climates } \\
\text { with monsoon seasons. }\end{array}$ & $\begin{array}{l}\text { Solar-assisted heat pumps for space heating } \\
\text { applications with variable lift control to optimize } \\
\text { performance over a broad range of input } \\
\text { temperatures. }\end{array}$ \\
\hline $\begin{array}{l}\text { Efficient, low-volume air handlers with airtight } \\
\text { box and durable, airtight dampers. Integrated } \\
\text { ventilation air heat recovery and night vent } \\
\text { capabilities for low load homes. With small- } \\
\text { diameter ( } 3.5 \text { in.), high-velocity ( } 600 \text { fpm) air } \\
\text { distribution systems for easy l-joist integration. } \\
\text { Durable. Low leakage. Low noise. Modest } \\
\text { pressure drop. With installation guidelines to } \\
\text { ensure adequate air distribution and air mixing } \\
\text { for thermal comfort. Integrated with low capacity } \\
(20 \mathrm{kBtu}) 95 \%+\text { efficient furnace. }\end{array}$ & $\begin{array}{l}\frac{\text { Roof-integrated photovoltaic (PV)/thermal space }}{\text { heating and night cooling systems (collector }+} \\
\underline{\text { balance of system). }} \\
\text { Attic integrated night sky radiation cooling systems. }\end{array}$ \\
\hline High-efficiency, low-capacity (1-2 ton) variable & \\
\hline $\begin{array}{l}\text { capacity/variable refrigerant-flow heat pumps and air } \\
\text { conditioners with occupancy-based zoning control. } \\
\text { Ductless mini-splits with efficient air distribution and } \\
\text { low-cost refrigerant lines that are cost competitive } \\
\text { with ducted systems. }\end{array}$ & \\
\hline Cold climate heat pumps. & \\
\hline $\begin{array}{l}\text { Low fan power heat/energy recovery ventilation } \\
\text { systems including occupancy-based demand control } \\
\text { with homeowner feedback clearly showing operating } \\
\text { status. }\end{array}$ & \\
\hline $\begin{array}{l}\text { Less expensive and more efficient ground-source } \\
\text { heat pumps with parasitic energy use comparable to } \\
\text { best air source systems. }\end{array}$ & \\
\hline
\end{tabular}

* bold = high system benefits, underlined = system benefits not clear, italics = low system benefits

\footnotetext{
${ }^{20}$ The VHP A/C system goal is a 30\% reduction in annual energy use at an incremental cost of $\$ 1000$ relative to a current SEER 18/EER 13.4 two-speed system with tight ducts in conditioned space.
} 
Table 6. Category 6 - Community-Scale ZEH Systems

\begin{tabular}{|c|c|}
\hline $\begin{array}{l}\text { Opportunity/Need: } \\
\text { Seasonal thermal storage systems and } \\
\text { cost-effective when implemented on a }\end{array}$ & $\begin{array}{l}\text { eating cooling and power systems are most } \\
\text { scale. }\end{array}$ \\
\hline $\begin{array}{l}\text { Overall Risks: } \\
\text { Increased first costs and O\&M requiren } \\
\text { homeowners. }\end{array}$ & e barriers for builders, developers, and \\
\hline $\begin{array}{l}\text { Overall Cost/Performance Goals: } \\
\text { TBD }\end{array}$ & \\
\hline Priority 1: Modifications of Existing & Priority 2: Advanced Systems (High Risk) ${ }^{*}$ \\
\hline & $\begin{array}{l}\text { Efficient community-scale residential energy } \\
\text { systems including generation, distribution and } \\
\text { energy storage (cogen, district heating and } \\
\text { cooling, wind power, concentrating solar } \\
\text { thermal, biomass power systems, solar thermal } \\
\text { systems with seasonal storage, etc.). }\end{array}$ \\
\hline
\end{tabular}

* bold = high system benefits, $\underline{\text { underlined }}=$ system benefits not clear, italics = low system benefits 


\section{Multi-Year Zero-Energy Home Research Plan}

The initial research required to develop ZEH technologies and systems must be completed by 2015 in order to achieve net ZEHs by 2020. Because of the higher risks associated with advanced ZEH systems, the Building America Program is also initiating lab homes starting in 2009 to allow detailed evaluation of advanced systems under controlled operating conditions. At least one lab home at the $50 \%+$ savings level will be built by industry partners in each of the five Building America climate regions. The lab homes will be monitored for up to two years before being sold and replaced by lab homes with additional advanced systems.

The overall schedule for ZEH technology research and building integration research is summarized in Figure 6. Best available systems and materials will be used to achieve the $50 \%$ savings level in 2015, including initial development of a ZEH-ready envelope.

Successful projects from the expanded ZEH technology research program will be used to achieve the $70 \%$ savings level in 2018 and net ZEH by 2020. Key ZEH technology research outcomes on the critical path are noted with arrows in Figure 6.

\begin{tabular}{|c|c|c|c|c|c|c|c|c|c|c|c|c|c|}
\hline 4 & Multi-Year Building America Research Schedule & FY 09 & FY 10 & FY 11 & FY 12 & FY 13 & FY 14 & FY 15 & FY 16 & FY 17 & FY 18 & FY 19 & FY 20 \\
\hline \multirow[t]{4}{*}{$\mathbf{\nabla}$} & $50 \%$ Savings Level & & & & & & & \multirow{3}{*}{\multicolumn{5}{|c|}{ ZEH-Ready Envelope }} & \\
\hline & Stage 1: Best Available Systems+ZEH Envelope & \multicolumn{6}{|c|}{ 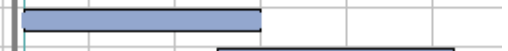 } & & & & & & \\
\hline & Stage 2: $50 \%$ Prototype Homes & & & \multicolumn{4}{|c|}{$\bar{\square}$} & & & & & & \\
\hline & Stage 3: $50 \%$ Communities & & & & & & & & & & & & \\
\hline & & & & & & & & \multirow{2}{*}{\multicolumn{4}{|c|}{ ZEH Equipment }} & & \\
\hline \multirow[t]{4}{*}{$\boldsymbol{\nabla}$} & $70 \%$ Savings Level & & & & & & & & & & & & \\
\hline & Stage 1: Initial ZEH Systems (Expanded Program) & & & & & & & & & & & & \\
\hline & Stage 2: $70 \%$ Lab and Prototype Homes & & & & & & & & & & & & \\
\hline & Stage 3: $70 \%$ Communities & & & & & & & & & & & & \\
\hline & & & & & & & & & & & & & \\
\hline \multirow[t]{4}{*}{$\boldsymbol{\nabla}$} & Net Zero Energy Homes & & & & & & & & & & & & \\
\hline & Stage 1: Final ZEH Systems & & & & & & & & & & & & \\
\hline & Stage 2: Net ZEH Lab and Prototype Homes & & & \multirow{3}{*}{\multicolumn{4}{|c|}{ ZEH Prototypes }} & & & & & & \\
\hline & Stage 3: Net ZEH Communities & & & & & & & & & & & & \\
\hline & & & & & & & & & & & & & \\
\hline & & & & & & & & & & & & & \\
\hline
\end{tabular}

Figure 6. Multi-Year ZEH Research Plan 


\section{Recommended Criteria for Selecting Projects for Expanded Zero-Energy Home Technology Research Program}

At least $\$ 4$ million per year for six years is required for research on low- to medium-risk ZEH systems and $\$ 8$ million per year for six years is required for research on high risk ZEH systems to achieve U.S. Department of Energy ZEH performance goals by 2020. This estimate is based on the assumption that 10 high potential projects will be included in the research program within each risk category, with an average annual cost of $\$ 400 \mathrm{~K} /$ year for each low- to medium-risk project and an average annual cost of $\$ 800 \mathrm{~K} /$ year for each high-risk project. Assuming a 20\% chance of success for high-risk projects and a $60 \%$ chance of success for low- to medium-risk projects over the six-year life of the program, the expanded ZEH technology research program will result in six successful low-risk projects and two successful high-risk projects. The corresponding requirement for the minimum energy savings that must be delivered by each successful project can be found by dividing the required $40 \%$ in incremental energy savings relative to a $50 \%$ house by the number of successful projects that are expected to be completed by 2015 ,

$(40 \%$ incremental savings $) / 8$ successful projects $=5 \%$ minimum savings per project.

To increase chances of success, projects that can provide savings greater than $5 \%$ should be given highest priority. Based on research progress, the initial set of technology opportunities that are included in the expanded research program can be downselected over time to focus on the subset of projects and solutions that are expected to provide the highest overall cost and performance benefits.

In addition to demonstrating the potential to achieve the $5 \%$ minimum incremental energy savings goal, each project must also demonstrate:

- A high likelihood of resolving technical barriers based on basic building science

- Validation of operating principles based on evaluation of a small-scale mockup

- Confirmation of performance based on evaluation of a full-scale prototype

- The identification and resolution of Level 1 to Level 3 risks

- The ability to implement the technology on a pilot production basis by 2015

- The ability to meet ZEH neutral cost criteria.

The energy used by a 50\% reference home in a cold climate is shown in Figure 7 . The largest energy targets of opportunity are large appliances, miscellaneous electrical uses, space heating, and lighting. The cold climate energy savings that must be delivered by an expanded ZEH technology research program are shown in Figure 8. Summaries for end uses and savings targets for other climates are included in Appendices C and D. 


\section{Distribution of Energy Uses in $\mathbf{5 0 \%}$ Reference Cold Climate Home}

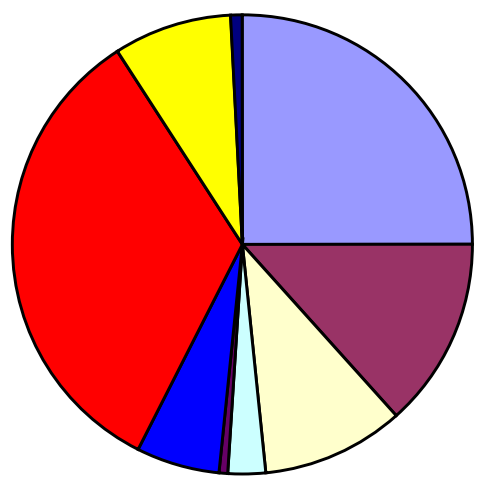

$\square$ Misc. (E)

$\square$ Lg. Appl. (E)

$\square$ Lights (E)

$\square$ Heat Fan (E)

$\square$ Cool Fan (E)

$\square$ Cooling (E)

$\square$ Heating $(\mathrm{G})$

$\square$ Hot Water $(\mathrm{G})$

Misc. (G)

Figure 7. Cold Climate Source Energy Uses to Be Targeted by an Expanded ZEH Technology Research Program (see Appendix D for end use targets in other climates)

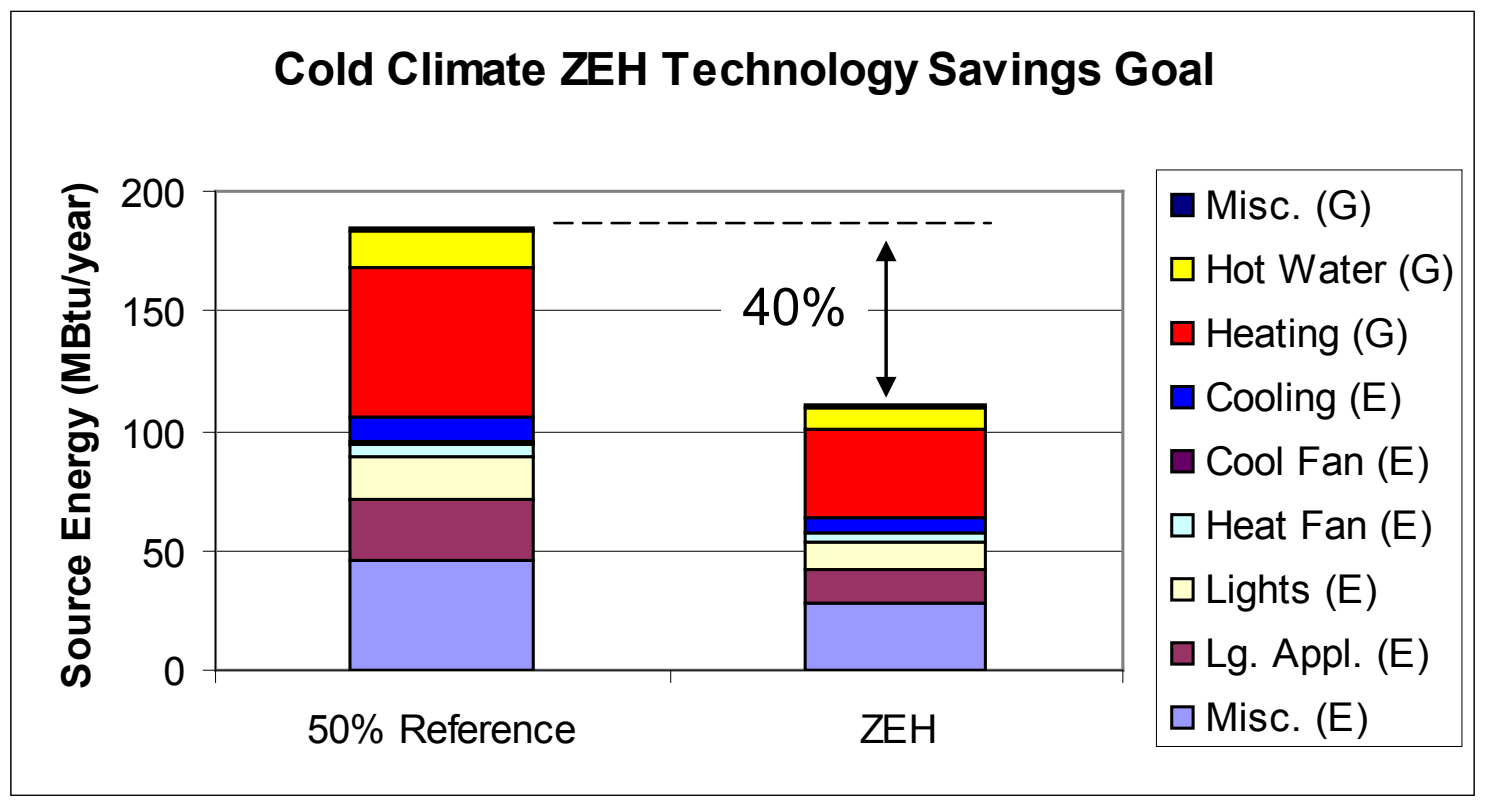

Figure 8. Energy Savings to Be Provided by an Expanded ZEH Technology Research Program (see Appendix C for a summary of energy saving opportunities in other climates) 


\section{Conclusions}

Significant increases in residential energy efficiency are required to meet emerging global and U.S. energy efficiency goals. New technologies and systems are required that, in combination, increase whole-house energy savings by $40 \%$ relative to the savings provided by current best available components and systems (Figure 9).

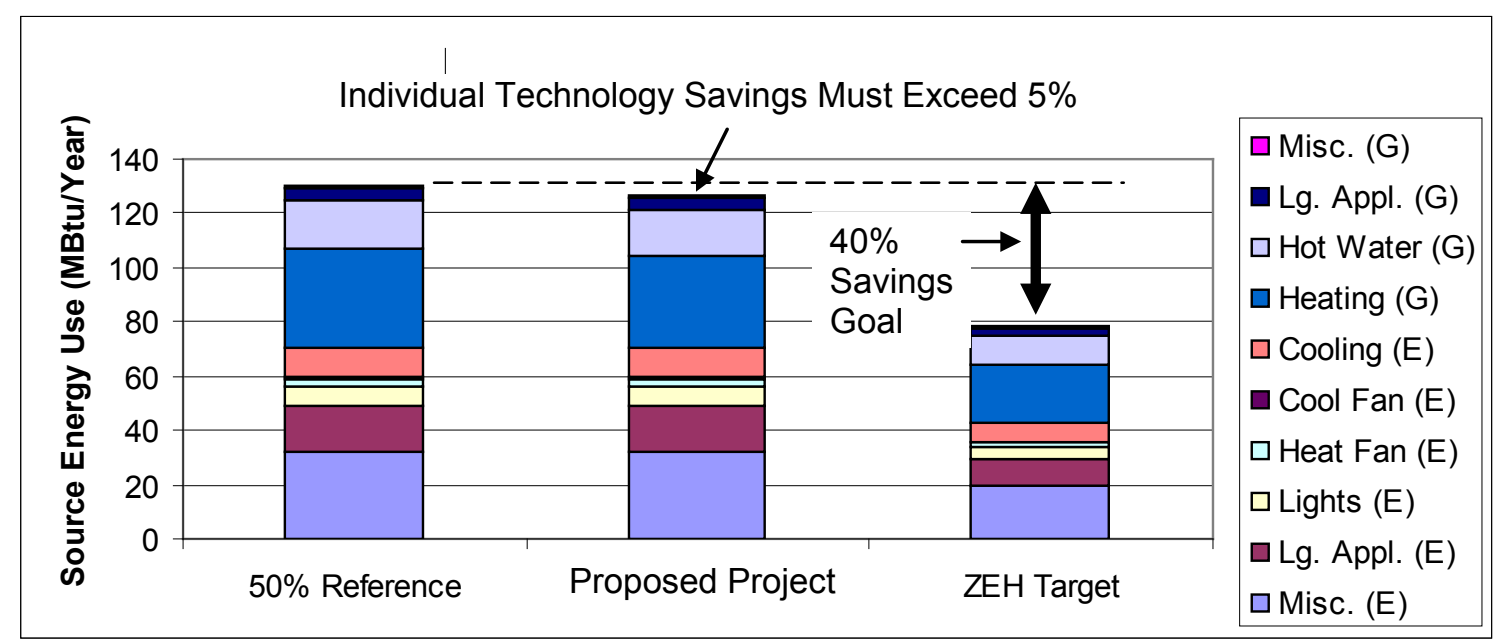

Figure 9. Minimum Energy Savings Requirement for ZEH Technologies Projects

In addition to providing significant energy savings, new technologies and systems must also directly address the risks that limit broad use of new products by builders, contractors, and homeowners:

- Level 1 Risk Reduction - The technology must meet minimum builder, contractor, and homeowner performance and reliability, O\&M, and durability requirements to be used in new and existing homes. It must provide high potential value to builders, contractors, and homeowners.

- Level 2 Risk Reduction - The design, construction, and commissioning requirements for integrating the new technology into homes must be understood and validated. Builders, contractors, and code officials must understand best practice design details, commissioning procedures, construction sequencing, costs, and benefits.

- Level 3 Risk Reduction - The field training, quality assurance/quality control, and commissioning requirements for the technology must be understood and included as part of a production construction process to ensure that potential savings and benefits are achieved when the technology is broadly implemented.

An expanded residential energy efficiency research program that includes system impact assessments, exploratory research, and component development research is required to achieve the U.S. Department of Energy goal of cost-neutral net ZEHs by 2020. 


\section{Appendix A - \\ Reference Technology Packages for $\mathbf{5 0 \%}$ Homes}

This appendix provides reference whole-house technology packages ${ }^{21}$ that target the Building America 50\% savings level for cities within each major climate region. An additional $20 \%$ in whole-house efficiency savings relative to the Building America benchmark (equivalent to $40 \%$ in additional savings relative to a $50 \%$ house) is required to achieve net ZEHs by 2020 . The $50 \%$ technology packages combine a ZEH-ready envelope with best available equipment. Building America research on these packages is scheduled to be completed by 2015 .

These reference packages were developed for a two-story, three-bedroom, $2500-\mathrm{ft}^{2}$, westfacing house with an 18\% window-to-floor area ratio using BEopt version 0.8.7 cost and performance values and Building America occupant usage profiles. For the optimizations, energy costs are based on current Energy Information Administration average annual values and are assumed to increase at the same rate as general inflation.

\section{0\% Reference: Marine Climate Region (Seattle)}

- $2 \times 6+\mathrm{R}-21$ cavity + 1.5-in. exterior insulating sheathing

- R-50 ceiling assembly

- $\quad .00015$ SLA (2.6 $\left.\mathrm{ACH}_{50}\right)$

- Low-e/std SHGC glazing, argon fill (0.29 U-value, 0.30 SHGC)

- $\quad 90 \%$ compact fluorescent lamp (CFL) lighting

- SEER 15+ A/C

- $\quad$ Annual fuel utilization efficiency (AFUE) 90+ furnace $\underline{O R}$ heating season performance factor (HSPF) 8.8+ heat pump

- Ducts in conditioned space

- $\quad$ Gas tankless hot water, EF 0.8+ OR premium electric, EF 0.95+ and 64- $\mathrm{ft}^{2}$ closed-loop solar system

- $\quad$ ENERGY STAR® appliances

\footnotetext{
${ }^{21}$ These technology packages are provided as examples, not as prescriptive specifications or requirements. Alternative or equivalent approaches may also be appropriate, depending on building type, location, and builder and homeowner preferences.
} 


\section{0\% Reference: Hot Humid Climate Region (Houston)}

- $2 \times 6, \mathrm{R}-21$ cavity

- R-30 ceiling assembly

- $\quad .00015$ SLA (2.6 $\left.\mathrm{ACH}_{50}\right)$

- $\quad$ Low-e/low-SHGC glazing (0.30 U-value, 0.26 SHGC)

- $\quad 90 \%$ CFL lighting

- SEER 15+ A/C

- $\quad$ AFUE 90+ furnace OR HSPF 8.8+ heat pump

- Ducts in conditioned space

- $\quad$ Gas tankless hot water, EF 0.8+ OR premium electric, EF 0.95+ and $32-\mathrm{ft}^{2}$ integrated collector/storage solar system

- $\quad$ ENERGY STAR appliances

\section{0\% Reference: Hot/Mixed Dry (Phoenix)}

- $2 \times 6+$ R-19 cavity

- $\quad \mathrm{R}-30$ ceiling assembly

- .0003 SLA $\left(5.3 \mathrm{ACH}_{50}\right)$

- Low-e/low-SHGC glazing (0.30 U-value, 0.26 SHGC)

- $\quad 90 \%$ CFL lighting

- SEER $13 \mathrm{~A} / \mathrm{C}$

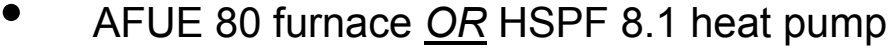

- Ducts in conditioned space

- $\quad$ Gas tankless hot water, EF 0.8+ $\underline{O R}$ electric, EF 0.9+

- $\quad$ ENERGY STAR appliances 


\section{0\% Reference: Mixed Humid (Atlanta)}

- $2 \times 6+$ R-21 cavity

- R-40 ceiling assembly

- $\quad .00015$ SLA (2.6 $\left.\mathrm{ACH}_{50}\right)$

- Low-e/low-SHGC glazing (0.30 U-value, 0.26 SHGC)

- $\quad 90 \%$ CFL lighting

- SEER 15+ A/C

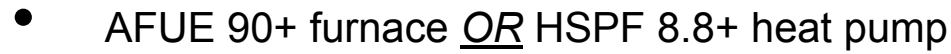

- Ducts in conditioned space

- Gas tankless hot water, EF 0.8+ OR premium electric, EF 0.95+ and 64-ft ${ }^{2}$ closed-loop solar system

- $\quad$ ENERGY STAR appliances

\section{0\% Reference: Cold Climate Region (Chicago)}

- $2 \times 6$, R-21 cavity +1 in. exterior insulating sheathing

- R-50 ceiling assembly

- R-10 basement

- $\quad .00015 \operatorname{SLA}\left(2.6 \mathrm{ACH}_{50}\right)$

- Triple-pane, low-e (0.25 U-value, 0.35 SHGC)

- $\quad 90 \%$ CFL lighting

- SEER 18 AC

- $\quad$ AFUE 90+ furnace OR HSPF 9.2 heat pump

- Ducts in conditioned space

- $\quad$ Gas tankless hot water, EF 0.8+ OR premium electric, EF 0.95+ and 64-ft ${ }^{2}$ closed-loop solar system

- ENERGY STAR appliances 


\section{Appendix B -}

\section{Residential Efficiency Gap}

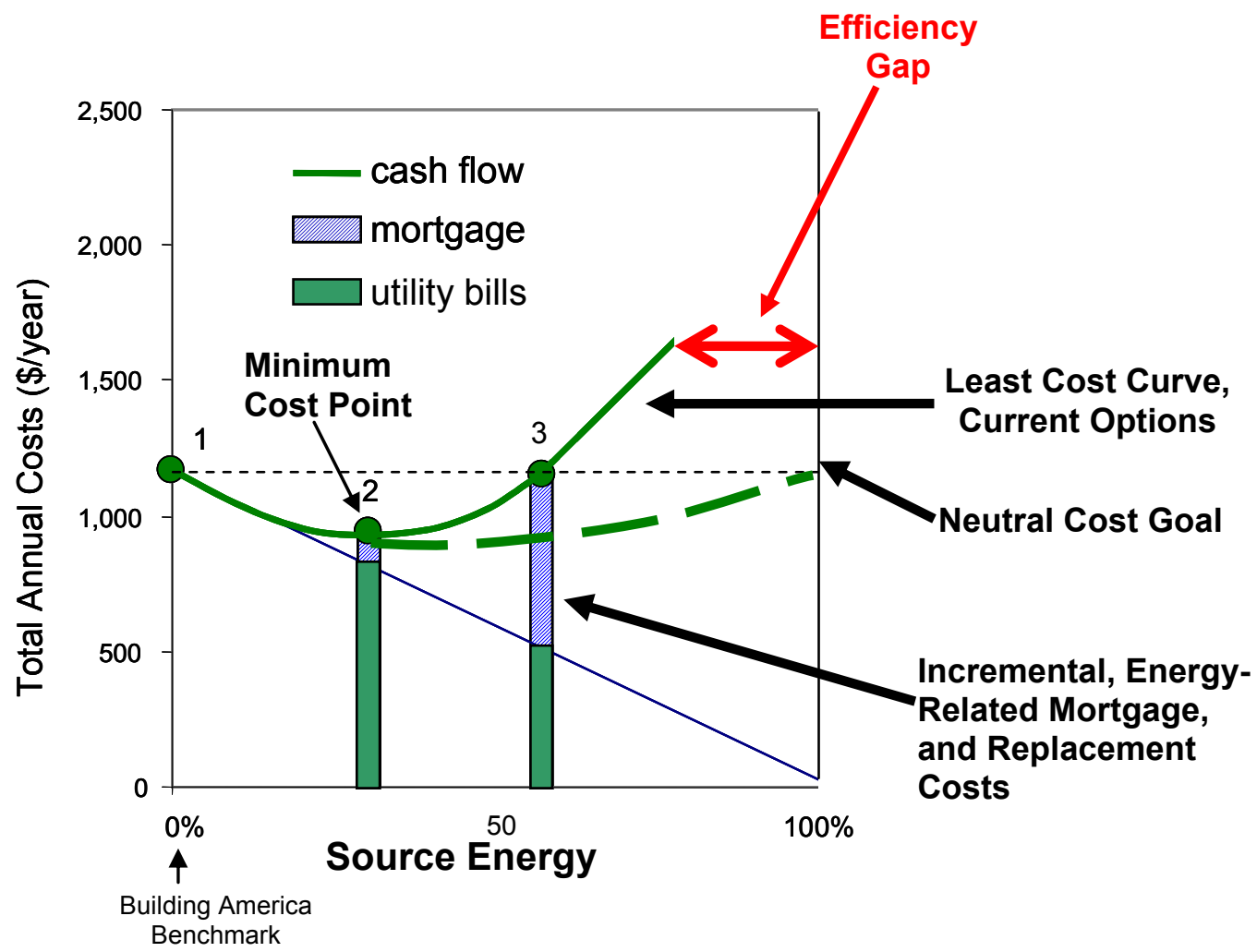

Figure B-1. Example Cost/Performance Curve

The cost and performance curves in this appendix show the magnitude of the efficiency gap that that must be filled to achieve net ZEHs by 2020 in different climates. This analysis used the same assumptions, building geometry, and cities as Appendix A. 


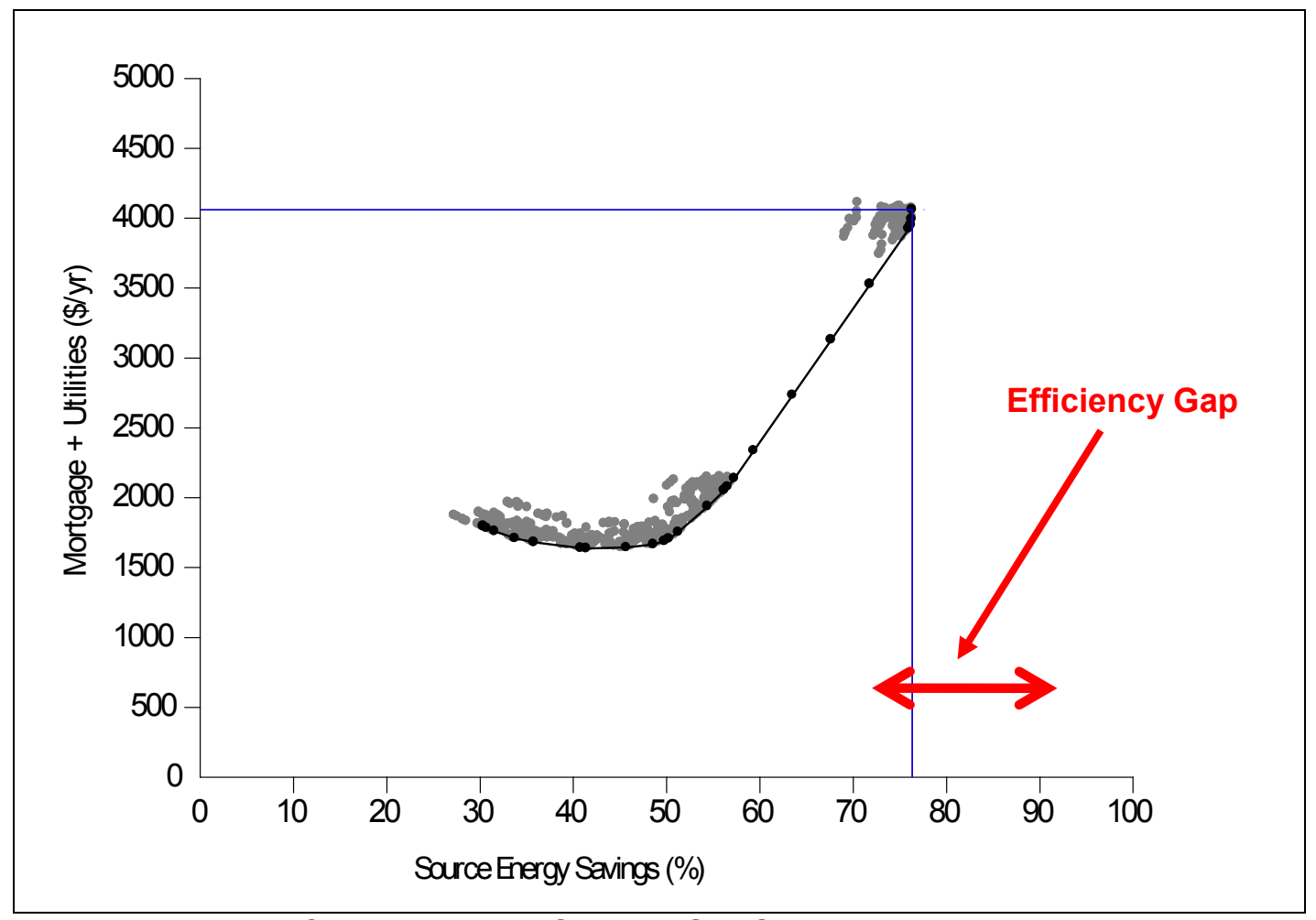

Figure B-2. Marine Climate Region (Seattle), Gas Space Heating

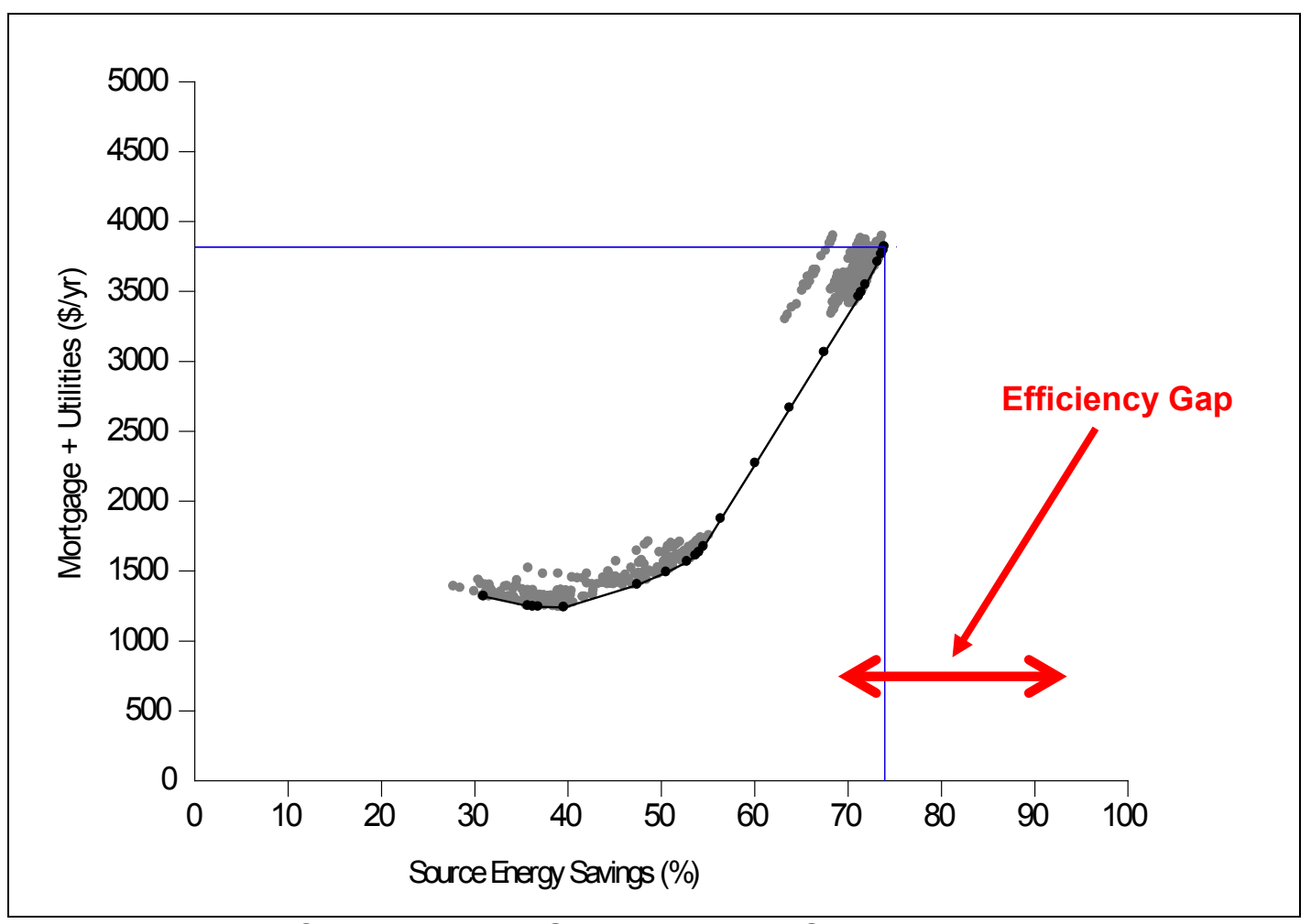

Figure B-3. Marine Climate Region (Seattle), Electric Space Heating 


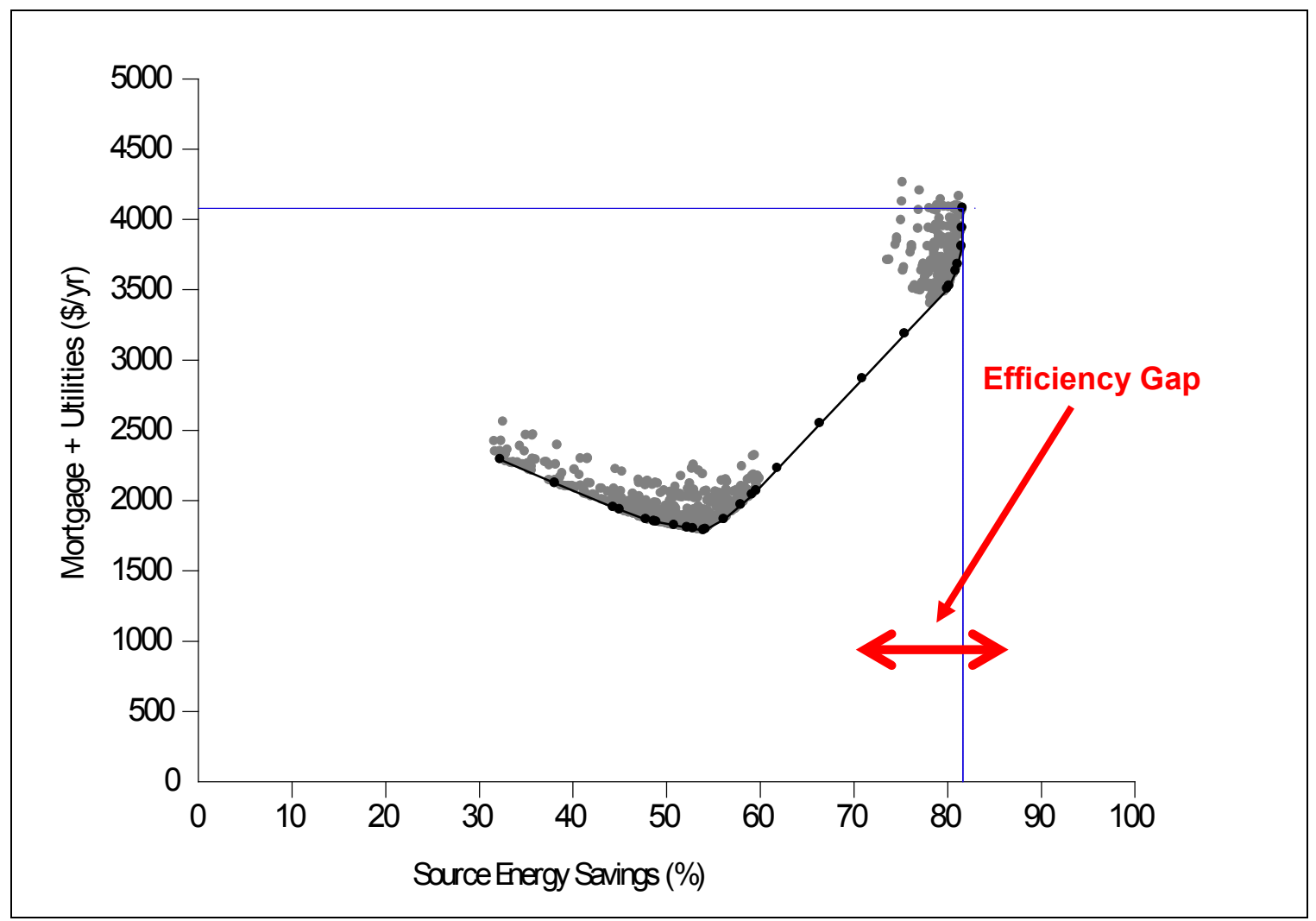

Figure B-4. Hot Humid Climate Region (Houston), Gas Space Heating

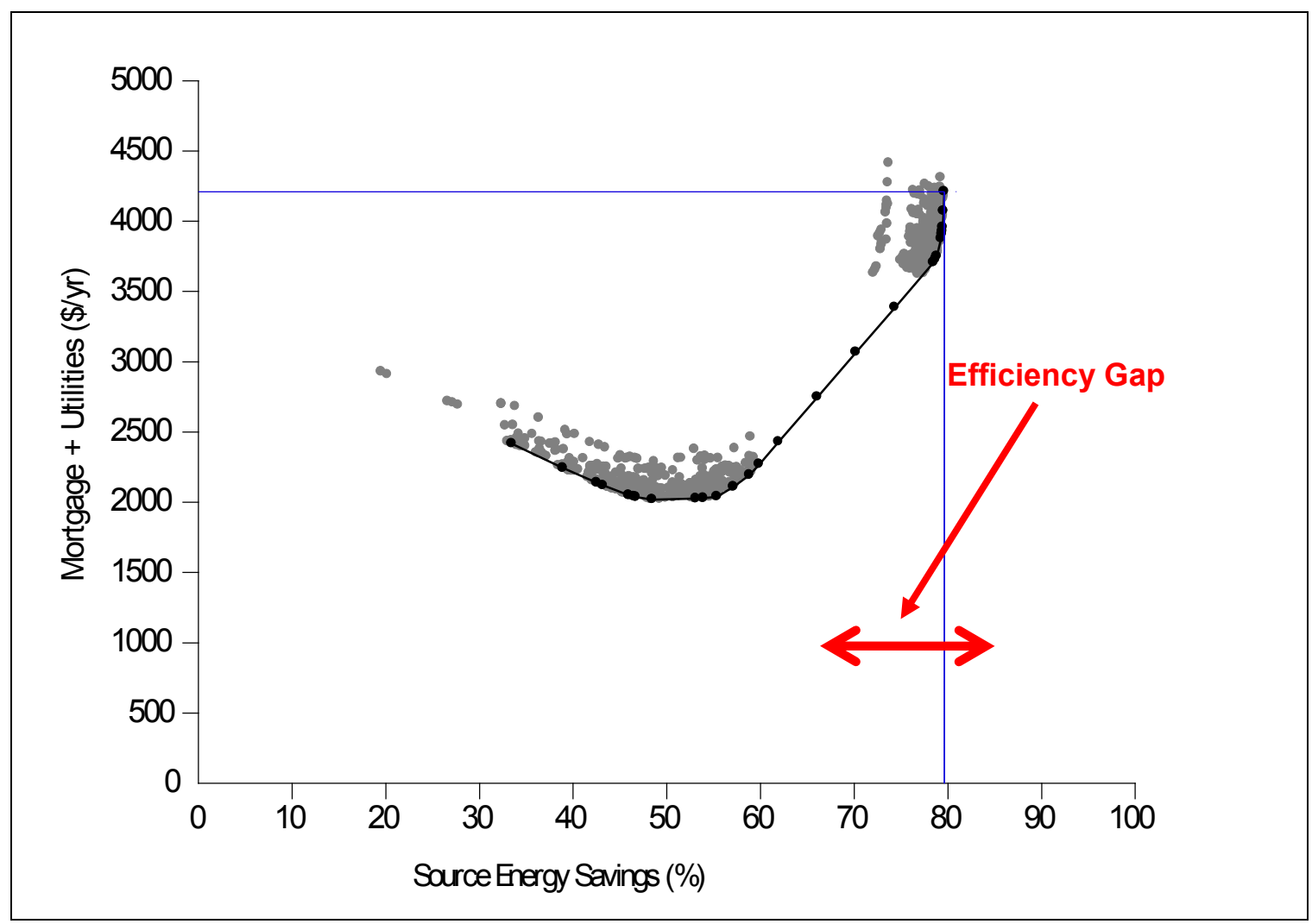

Figure B-5. Hot Humid Climate Region (Houston), Electric Space Heating 


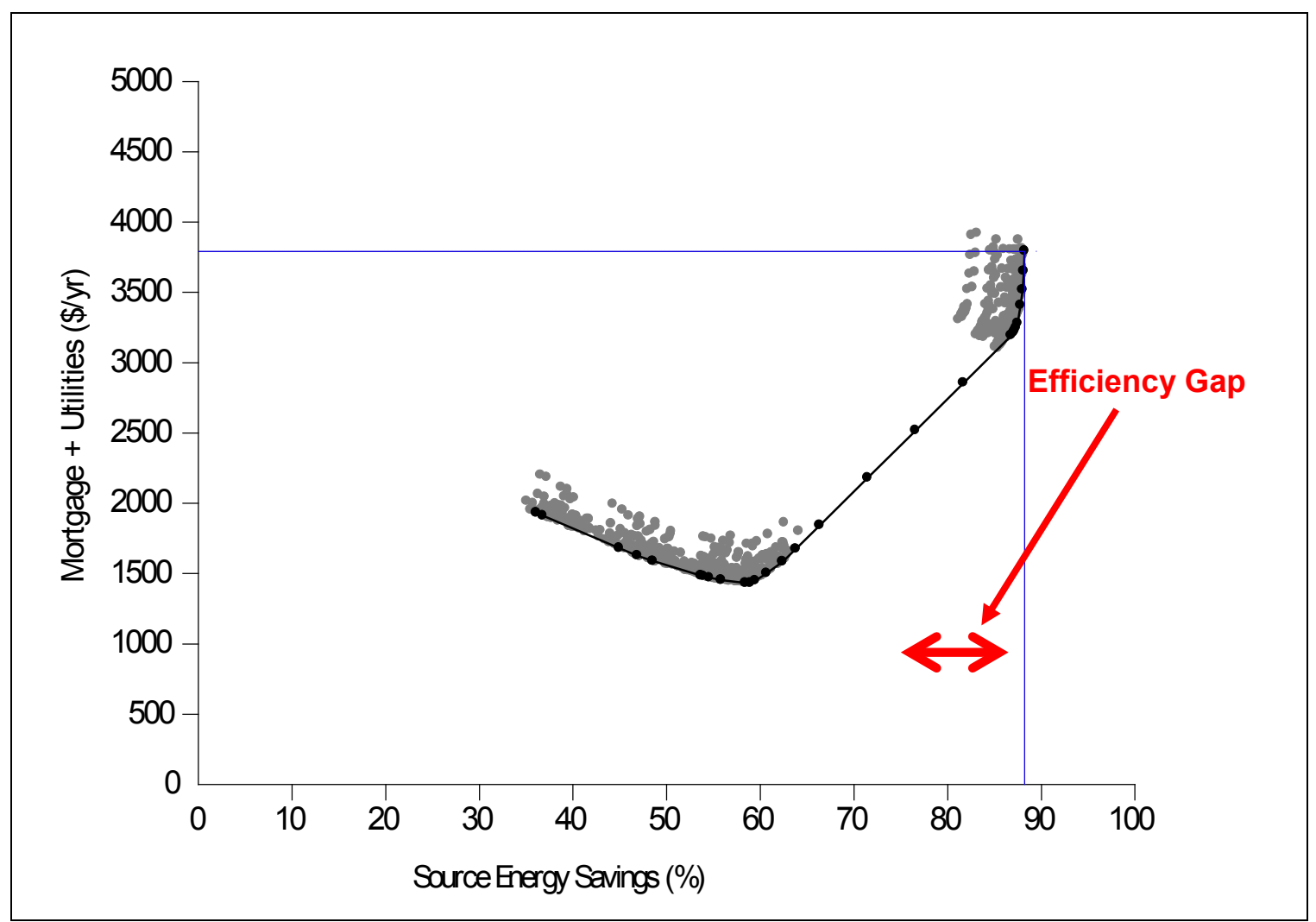

Figure B-6. Hot/Mixed Dry Climate Region (Phoenix), Gas Space Heating

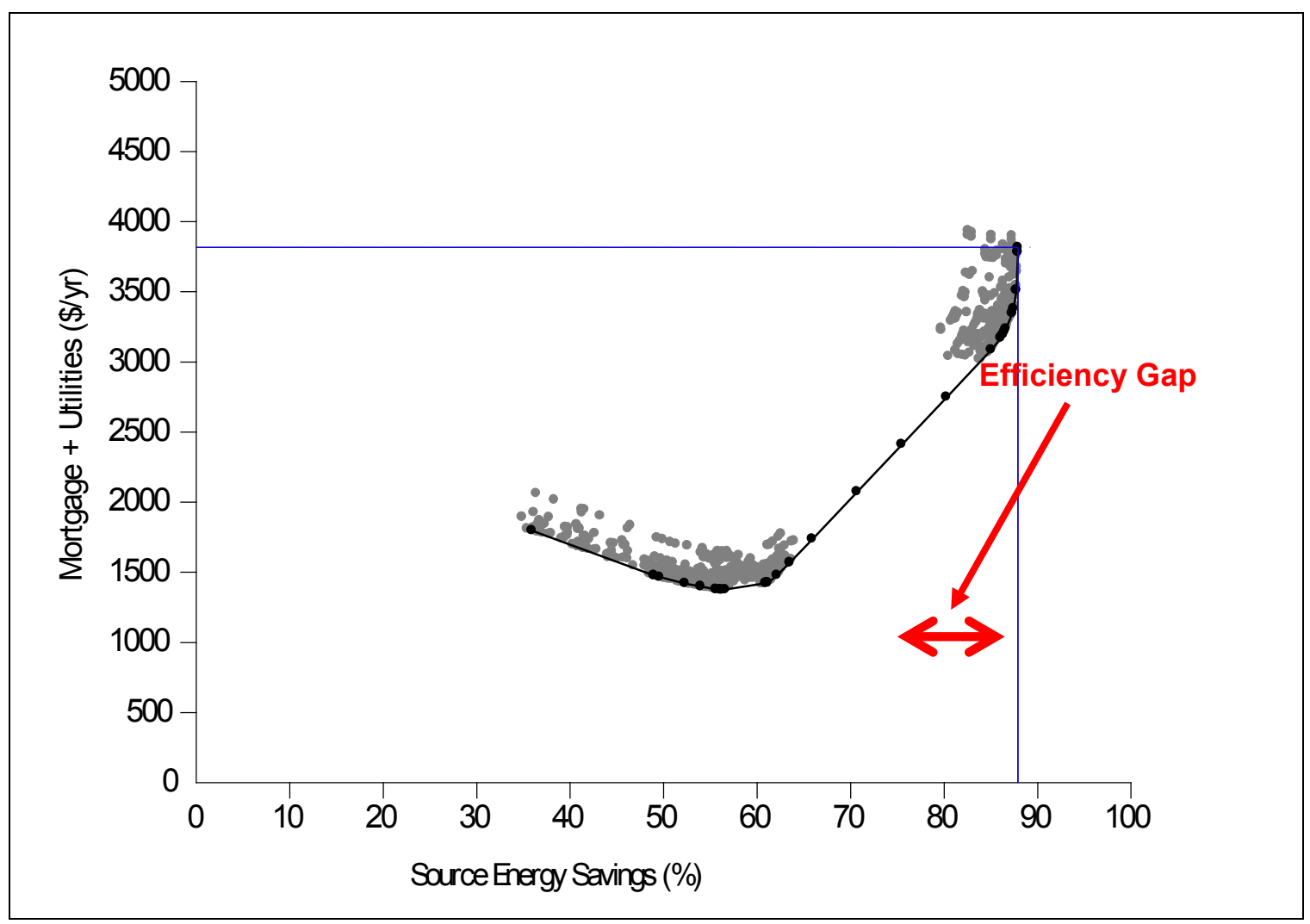

Figure B-7. Hot/Mixed Dry Climate Region (Phoenix), Electric Space Heating 


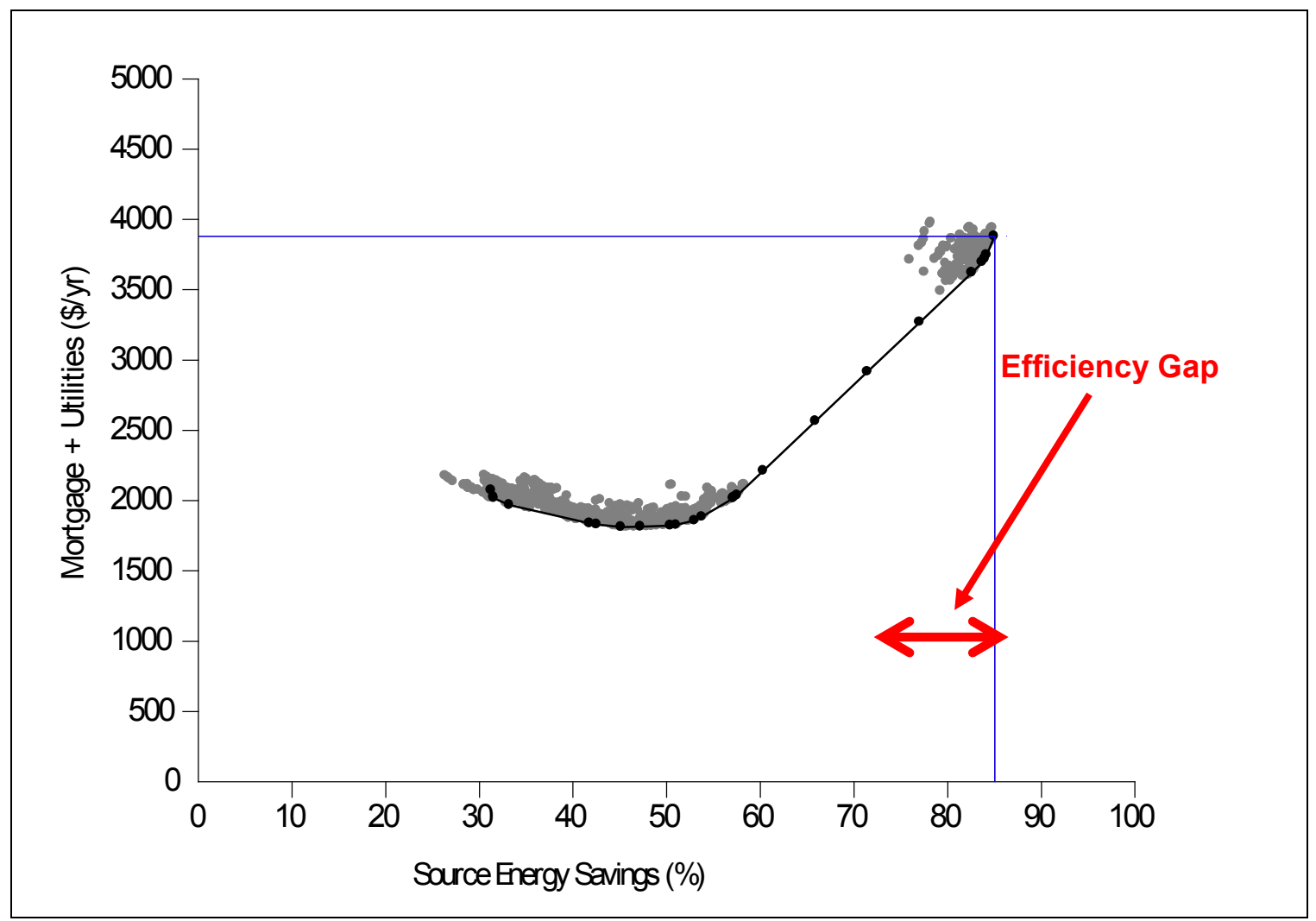

Figure B-8. Mixed Humid Climate Region (Atlanta), Gas Space Heating

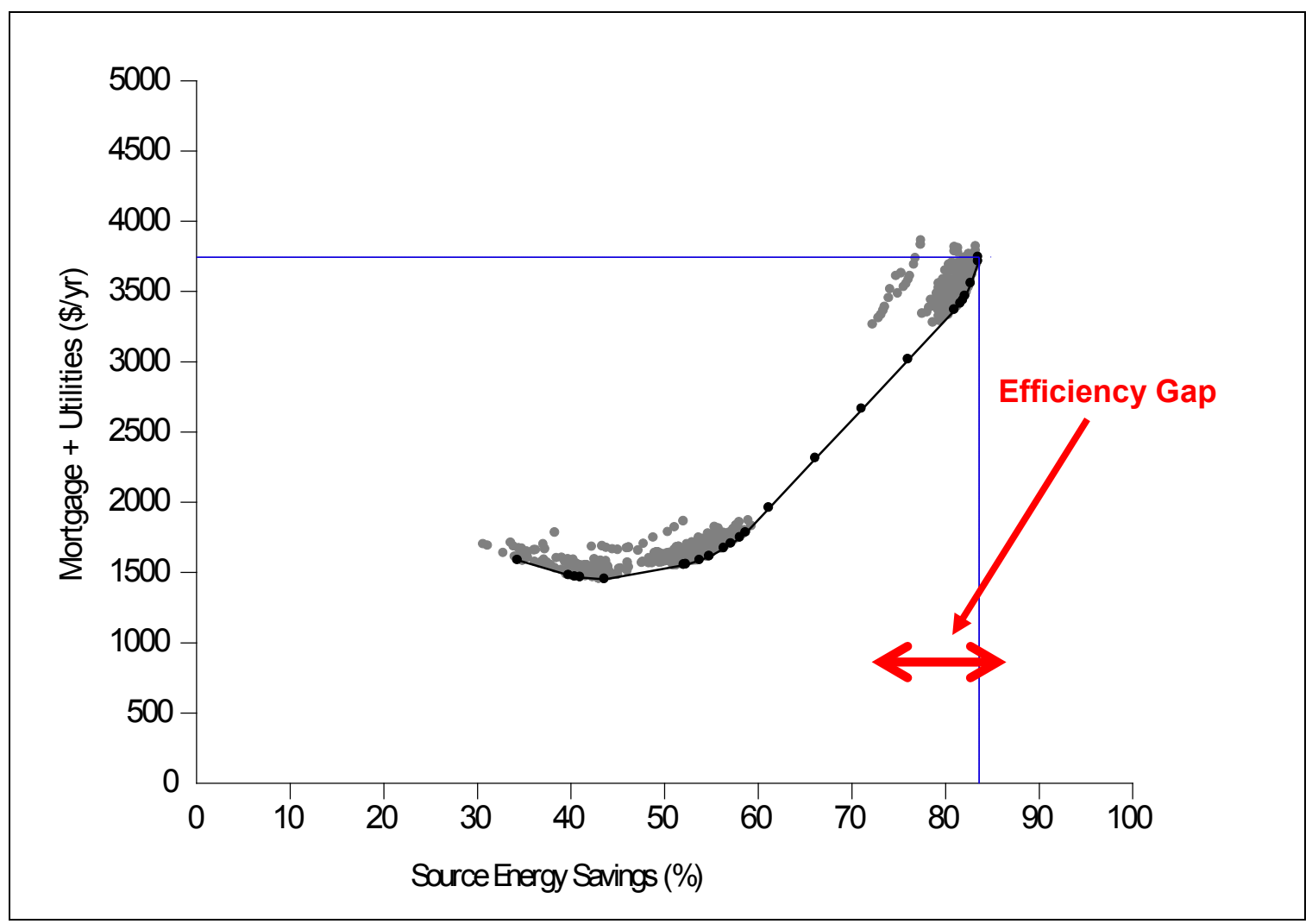

Figure B-9. Mixed Humid Climate Region (Atlanta), Electric Space Heating 


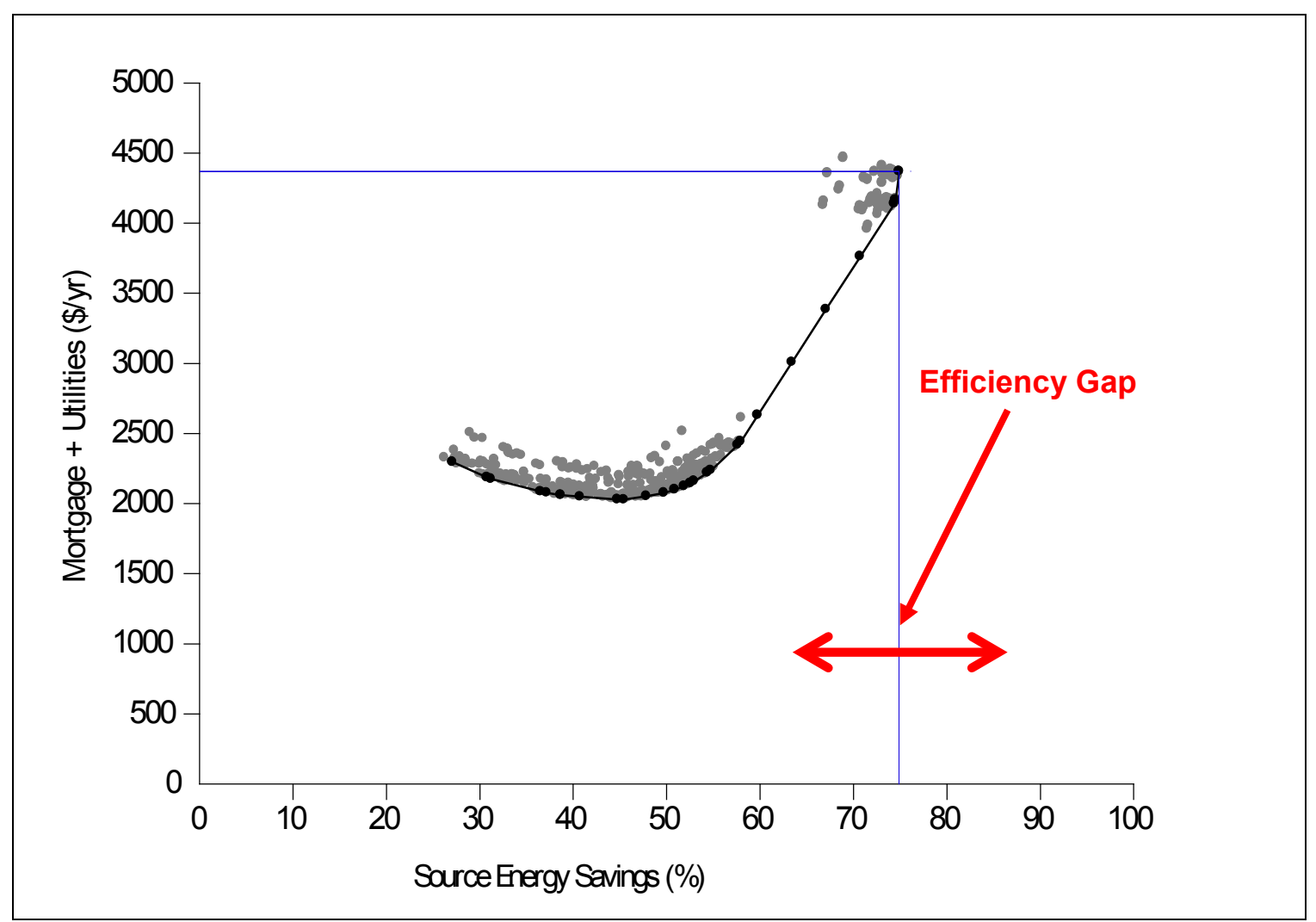

Figure B-10. Cold Climate Region (Chicago), Gas Space Heating

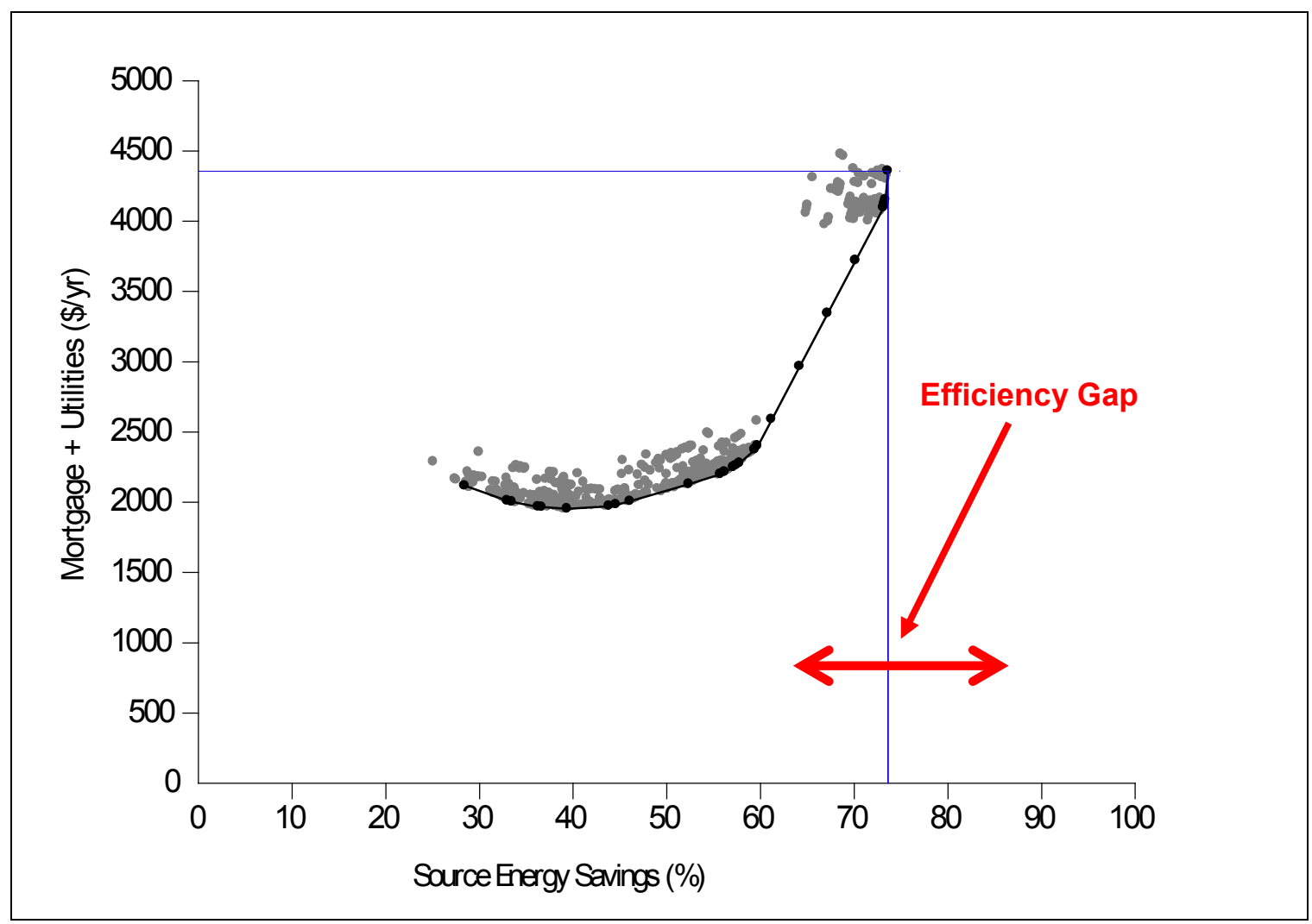

Figure B-11. Cold Climate Region (Chicago), Electric Space Heating 


\section{Appendix C - \\ Overview of Zero-Energy Home Technology Energy Saving Goals}

Appendix $C$ summarizes the additional savings by end use ${ }^{22}$ that must be achieved over the next six years to fill the efficiency gaps shown in appendix B. A uniform savings goal of $20 \%{ }^{23}$ was used for all climates to develop these graphs. The gaps shown in Appendix B vary from $15 \%$ to $25 \%$, depending on climate.

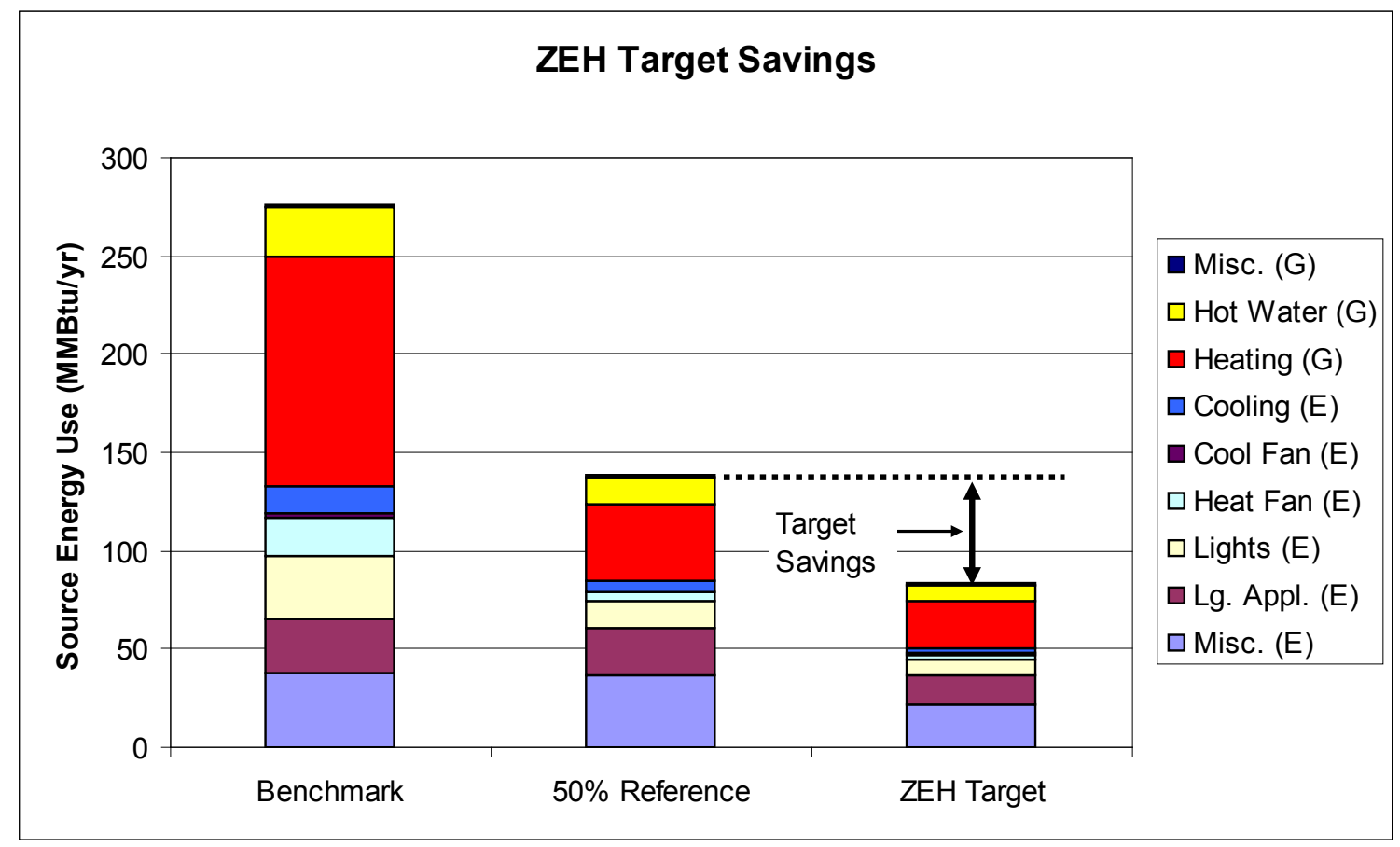

Figure C-1. Northern Marine Climate Region (Seattle), Gas Space Heating

${ }^{22}$ Calculations are based on the same assumptions, building type, and locations used in Appendix A.

${ }^{23}$ The $20 \%$ savings goal is measured relative to the energy used by the Building America Benchmark house. These savings correspond to $40 \%$ of the source energy used by a $50 \%$ house. 


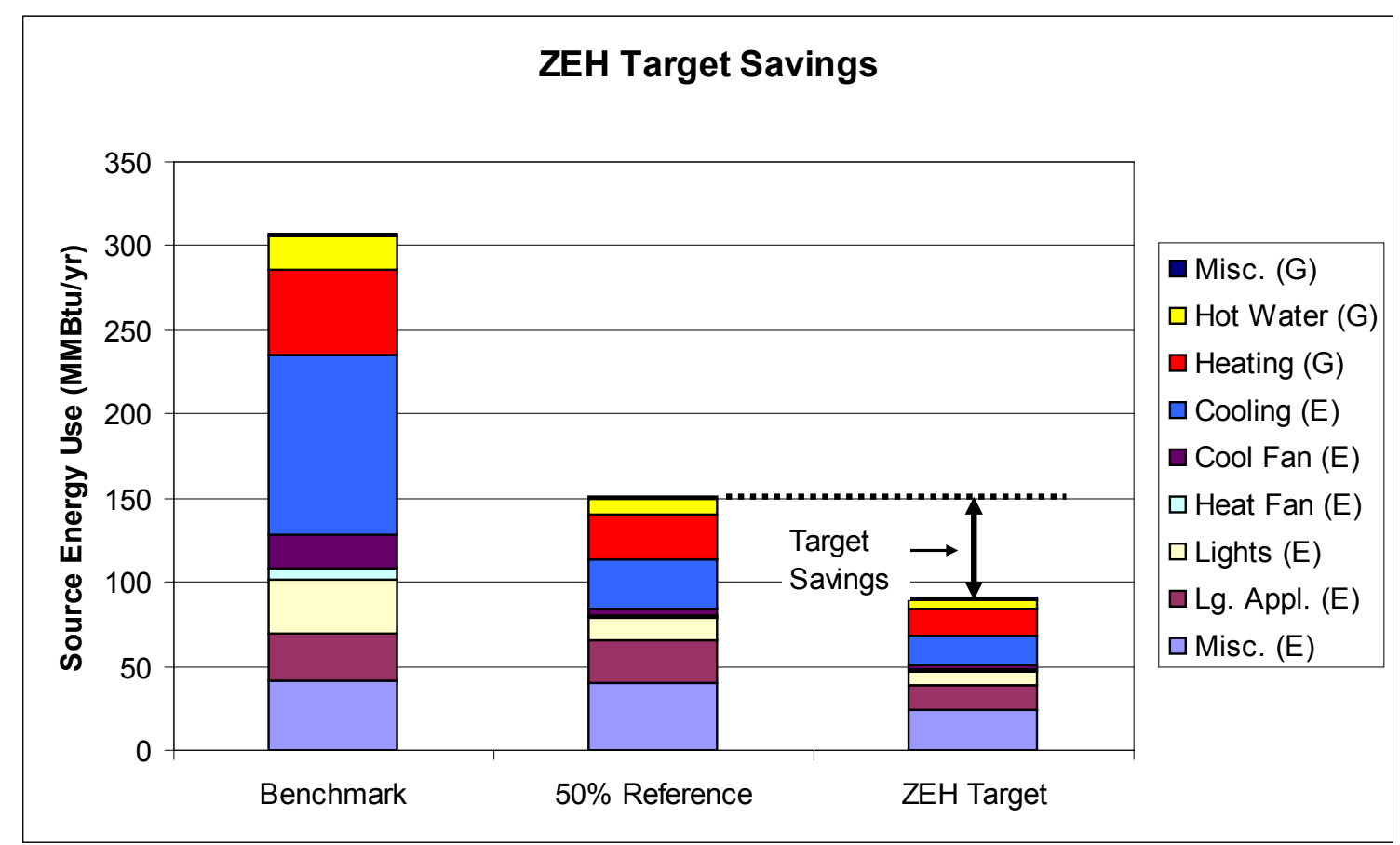

Figure C-2. Hot Humid Climate Region (Houston), Gas Space Heating

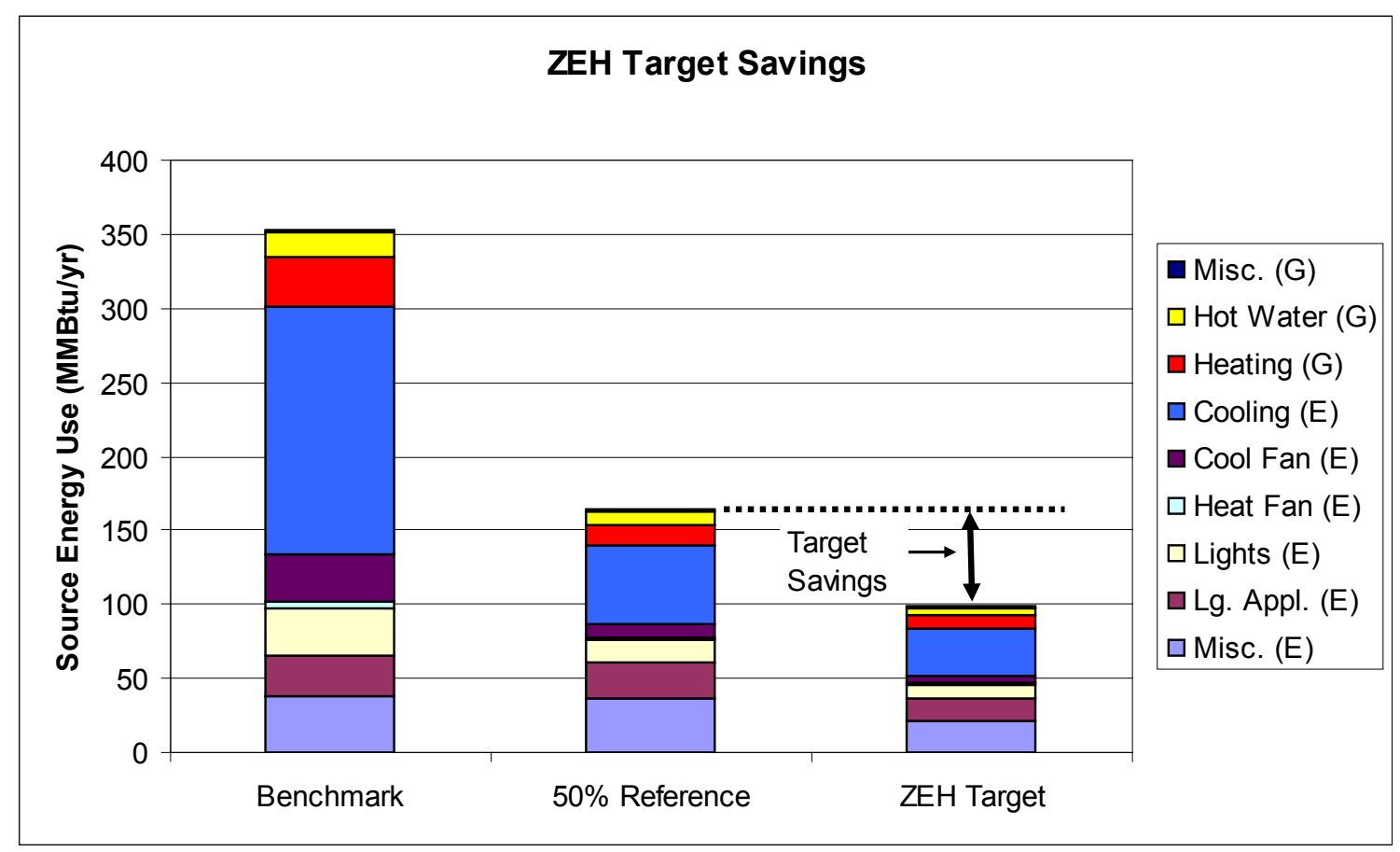

Figure C-3. Hot/Mixed Dry Climate Region (Phoenix), Gas Space Heating 


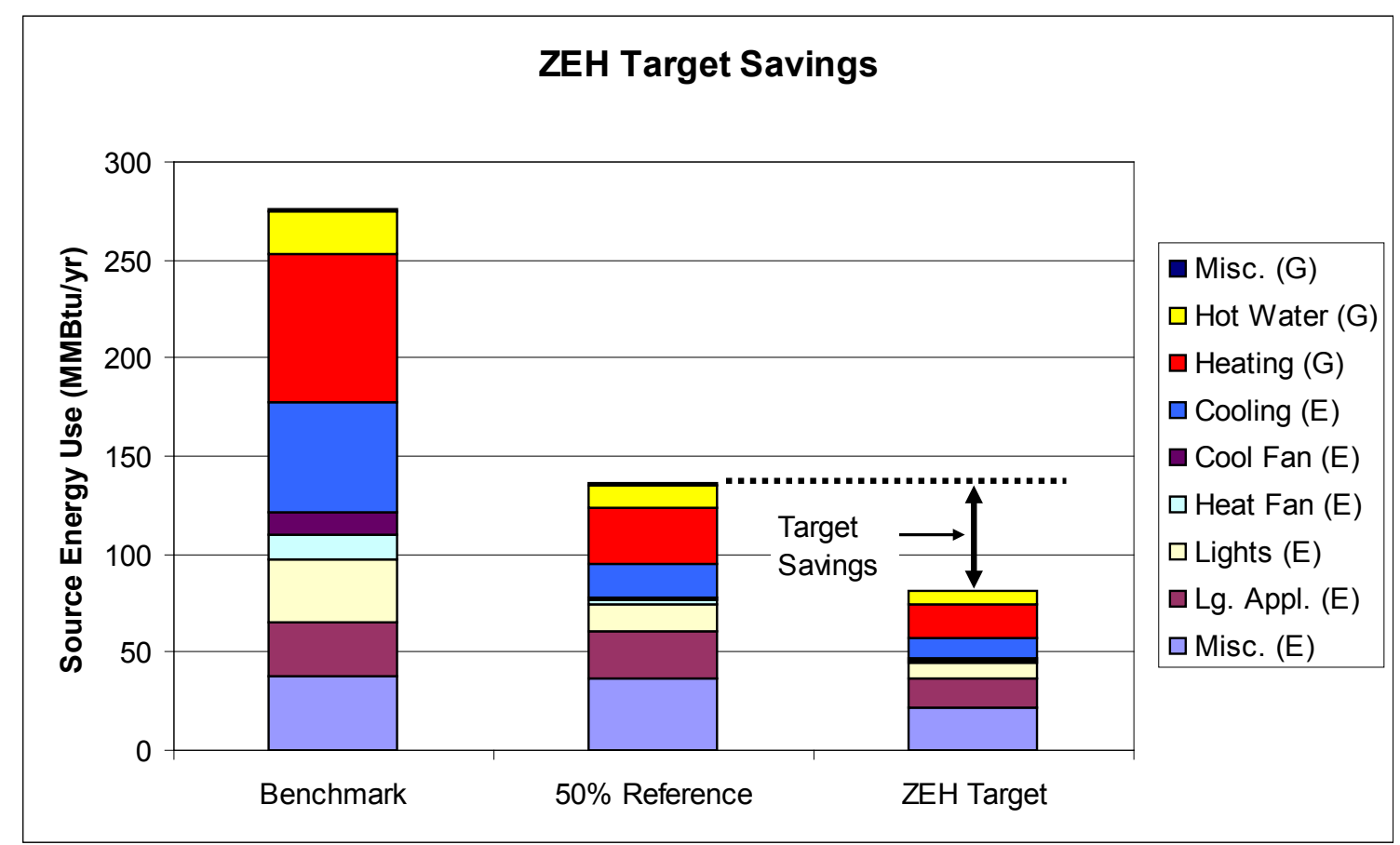

Figure C-4. Mixed Humid Climate Region (Atlanta), Gas Space Heating

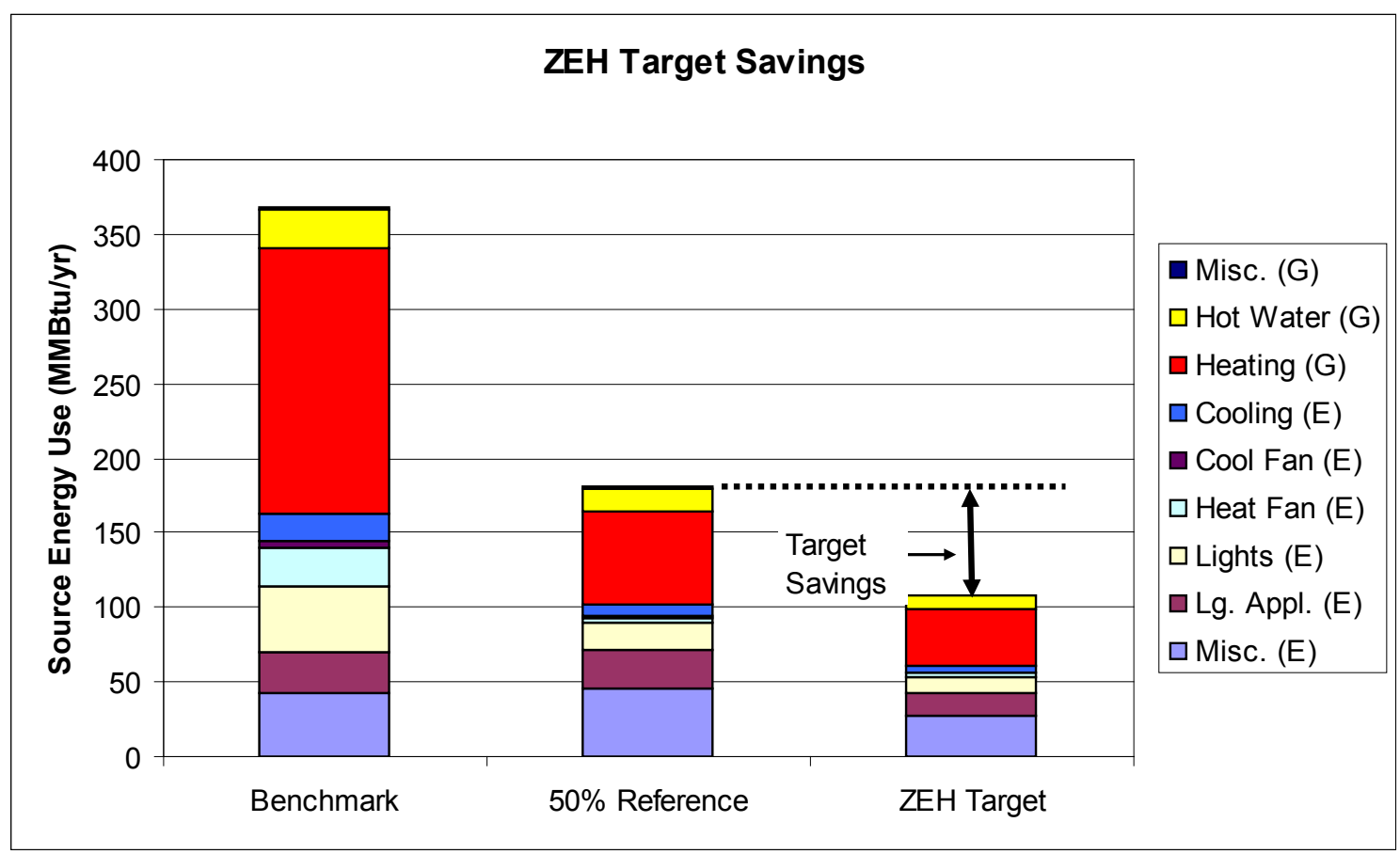

Figure C-5. Cold Climate Region (Chicago), Gas Space Heating 


\section{Appendix D - Source Energy End-Use Consumption in $\mathbf{5 0 \%}$ Reference Homes}

Appendix D summarizes the relative magnitudes of the energy end uses ${ }^{24}$ in homes that save $50 \%$ relative the Building America Benchmark in different climates. ${ }^{25}$ Large appliances, space conditioning, and miscellaneous electrical uses represent the largest individual targets of opportunity for additional energy savings in all climates. Lighting accounts for about $10 \%$ of whole-house energy use. Hot water energy use varies from 5\% in warm climates to $9 \%$ in cold climates.

\section{Source Energy Use (Total: 136 MMBtu/yr)}

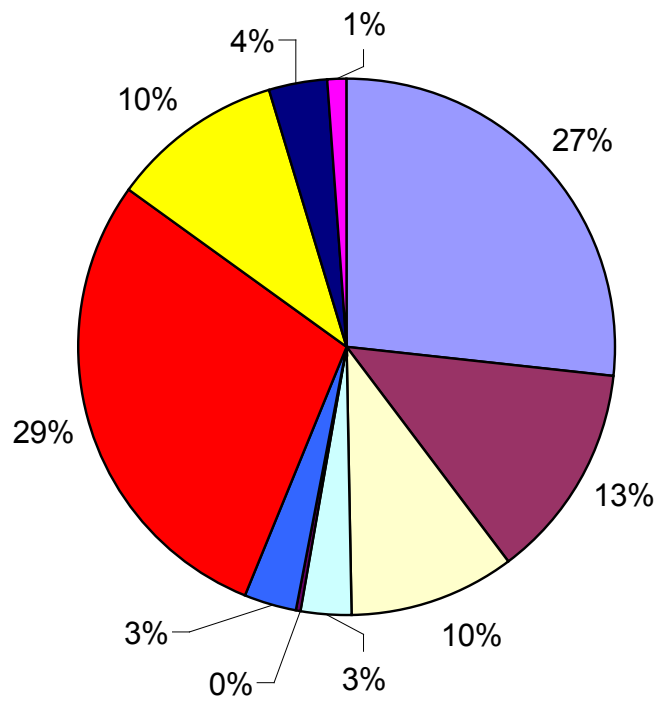

$\square$ Misc. (E)

$\square$ Lg. Appl. (E) $\square$ Lights (E)

$\square$ Heat Fan (E)

$\square$ Cool Fan (E) $\square$ Cooling (E)

$\square$ Heating (G)

$\square$ Hot Water (G)

- Lg. Appl. (G)

$\square$ Misc. (G)

Figure D-1. Marine Climate Region (Seattle), Gas Space Heating

${ }^{24}$ Calculations are based on the same assumptions, building geometry, and locations used in Appendix A.

${ }^{25}$ Research leading to initial community-scale implementation of $50 \%$ homes is currently scheduled to be completed in 2015 . 


\section{Source Energy Use (Total: 151 MMBtu/yr)}

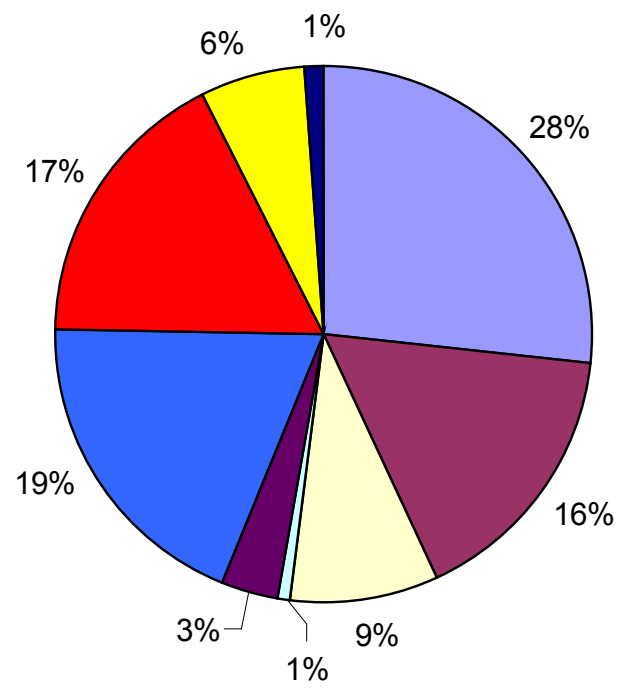

$\square$ Misc. (E) $\square$ Lg. Appl. (E) $\square$ Lights (E) $\square$ Heat Fan (E) $\square$ Cool Fan (E) $\square$ Cooling (E) $\square$ Heating (G) $\square$ Hot Water (G) - Misc. (G)

Figure D-2. Hot Humid Climate Region (Houston), Gas Space Heating

\section{Source Energy Use (Total: 164 MMBtu/yr)}

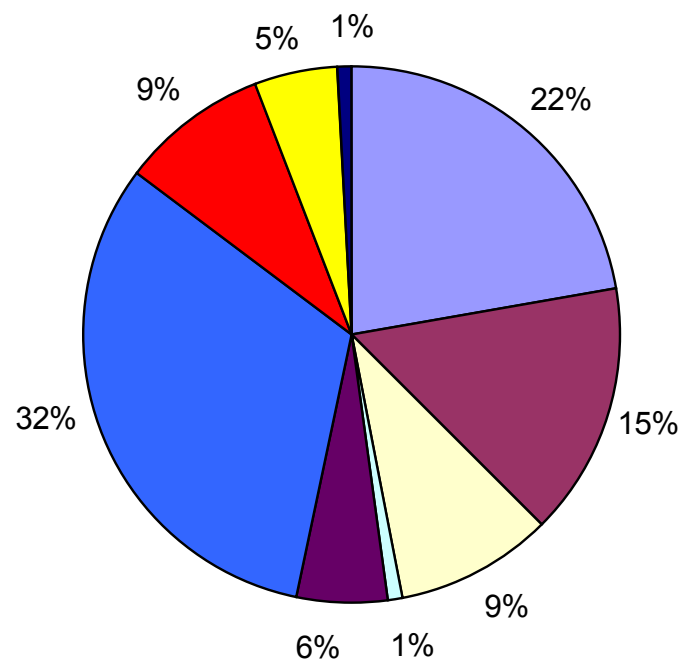

$\square$ Misc. (E)

$\square$ Lg. Appl. (E) $\square$ Lights (E)

$\square$ Heat Fan (E)

$\square$ Cool Fan (E) $\square$ Cooling (E)

$\square$ Heating (G)

$\square$ Hot Water (G) - Misc. (G)

Figure D-3. Hot/Mixed Dry Climate Region (Phoenix), Gas Space Heating 


\section{Source Energy Use (Total: 136 MMBtu/yr)}

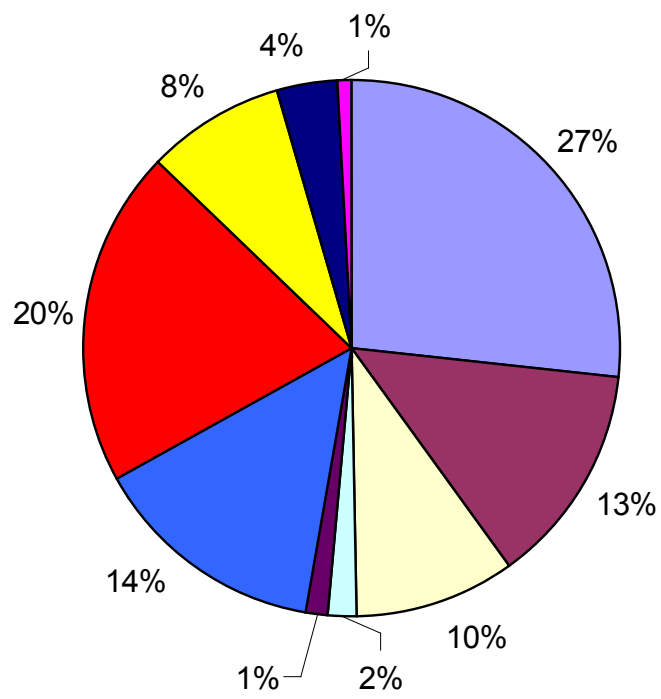

$\square$ Misc. (E)

$\square$ Lg. Appl. (E)

$\square$ Lights (E)

$\square$ Heat Fan (E)

$\square$ Cool Fan (E)

$\square$ Cooling (E)

$\square$ Heating (G)

$\square$ Hot Water (G)

- Lg. Appl. (G)

$\square$ Misc. (G)

Figure D-4. Mixed Humid Climate Region (Atlanta), Gas Space Heating

\section{Source Energy Use (Total: 181 MMBtu/yr)}

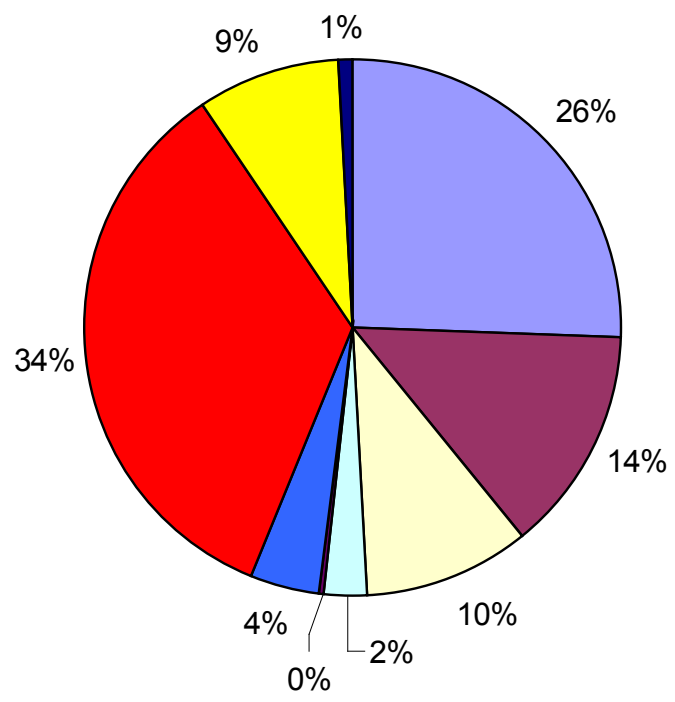

$\square$ Misc. (E)

$\square$ Lg. Appl. (E)

$\square$ Lights (E)

$\square$ Heat Fan (E)

$\square$ Cool Fan (E)

$\square$ Cooling (E)

$\square$ Heating (G)

$\square$ Hot Water (G)

aisc. (G)

Figure D-5. Cold Climate Region (Chicago), Gas Space Heating 


\section{Appendix E - Climate Sensitivity of Zero-Energy Home Pathways}

Critical ZEH performance gaps ${ }^{26,27,28,29}$ are defined in terms of the incremental source energy savings and incremental costs that must be achieved by new systems to successfully compete with the homes that are expected to be completed by the program in $2015 .^{30}$ New systems need to provide significant cost and/or performance benefits relative to the system solutions shown in Appendix A in order to fill the efficiency gaps shown in Appendix B. In addition to providing energy savings, the total amortized incremental cost of the engineered energy technology package in a ZEH must be comparable to the utility bill savings provided by the home to enable ZEHs to expand beyond high-value niche markets and achieve broad market acceptance. New residential system solutions that provide an additional $40 \%$ in savings relative to a $50 \%$ house must be developed between 2009 and 2015 in order to achieve net ZEHs by 2020. The following systems represent a minimum ${ }^{31}$ set of efficiency improvements required to achieve cost-neutral net ZEHs:

- High-R Wall Systems - Durable high-R wall systems for cold, northern marine, and mixed climates, leading to development of an R-30 wall assembly with an incremental cost of $\$ 2 / \mathrm{ft}^{2}$-floor area relative to an $\mathrm{R}-192 \times 6$ wall.

- Cold Climate DHW - DHW system with $\$ 2000$ incremental system cost and 30\% reduction in annual energy relative to a gas tankless hot water system with $\mathrm{EF}=0.8$.

- Cold Climate R-10 Window Assembly - R-10 window assembly with a minimum SHGC of 0.3 and cost of $\$ 20 / \mathrm{ft}^{2}$ (incremental cost of $\$ 4 / \mathrm{ft}^{2}$ of window area relative to current low-e windows).

- VHP A/C System ${ }^{32}$ - A/C system with $30 \%$ reduction in annual energy use and an incremental cost increase of $\$ 1000$ relative to a current two-speed SEER 18/EER 13.4 system with tight ducts in conditioned space.

- MEL Reduction - 30\% reduction in miscellaneous electrical energy use with an incremental cost of $\$ 1000$.

\footnotetext{
${ }^{26}$ The technology pathways shown in this appendix assume that the minimum set of cost and performance targets summarized above have been met. In addition, these packages assume that the installed PV system cost has been reduced to $\$ 3.30 / \mathrm{W}$. Yellow highlighted items indicate advanced systems that will be developed by an expanded ZEH technology research program.

${ }^{27}$ FY 2009 Residential AOP Evaluation Criteria, 3/30/2008.

${ }^{28}$ Critical Building America Technology Targets and Example Gate 1A Technology Packages, 3/30/2008.

${ }^{29}$ Cost performance targets were established using BEopt default cost data, assuming future PV costs of $\$ 3.30 /$ Watt. Analysis was done for a west-facing $2500-\mathrm{ft}^{2}$ house with $16 \%$ window area. "Neutral cost" means that a homeowner moving from a 1990s house into a new home will have the same energy-related costs (utility bills plus financing costs for energy upgrades) as they had in their old house (utility bills only). Incremental costs were evaluated relative to IECC 2003.

${ }^{30}$ Examples of the technologies that will be used in these homes are shown in Appendix A.

${ }^{31}$ This is a minimum set because only space conditioning, hot water, and MELs have been targeted. An additional $3 \%-5 \%$ of savings will be contributed by solid-state lighting if LED price points and performance continue to improve.

${ }^{32}$ The A/C performance goal is an overall installed system performance goal and includes savings from efficiency (improvements in COP), zoning, night cooling, evaporative cooling, heat recovery, and capacity modulation.
} 


\begin{tabular}{|l|l|}
\hline & Hot/Dry, 90\% Savings \\
\hline & Technology Option \\
\hline Walls & $2 \times 6+$ R-21 cavity (R-15 assembly) \\
\hline Ceiling & R-40 \\
\hline Infiltration & 0.0002 SLA (4 ACH50) \\
\hline Windows: Glass Type & $\begin{array}{l}\text { Low-e/low-SHGC glazing (0.30 U-value, } 0.26 \\
\text { SHGC) }\end{array}$ \\
\hline Refrigerator & ENERGY STAR \\
\hline Dishwasher & ENERGY STAR \\
\hline Washer/Dryer & ENERGY STAR \\
\hline Lighting & LED \\
\hline HVAC & AFUE 90+ furnace, VHP A/C System \\
\hline Ducts & Tight (mastic, 5\% leakage), in conditioned space \\
\hline Water Heater & Gas tankless, EF 0.8+ \\
\hline Other & $30 \%$ reduction in MELs \\
\hline PV & $5.5-k W$ dc PV system \\
\hline $\begin{array}{l}\text { Incremental Cost } \\
\text { (relative to code house) }\end{array}$ & \$12/ft ${ }^{2}$ \\
\hline
\end{tabular}




\begin{tabular}{|l|l|}
\hline & Cold, 90\% Savings \\
\hline & Technology Option \\
\hline Walls & $\begin{array}{l}2 \times 6+\text { R-19 cavity+ 2-in. foam sheathing (R-30 } \\
\text { wall assembly) }\end{array}$ \\
\hline Ceiling & R-50 \\
\hline Foundation & R-15 basement \\
\hline Infiltration & 0.0001 SLA (2 ACH50) \\
\hline Windows: Glass Type & R-10 window, std SHGC (0.3 SHGC) \\
\hline Refrigerator & ENERGY STAR \\
\hline Dishwasher & ENERGY STAR \\
\hline Washer/Dryer & ENERGY STAR \\
\hline Lighting & LED \\
\hline HVAC & AFUE 90+ furnace; VHP A/C System \\
\hline Ducts & Tight (mastic, 5\% leakage), in conditioned space \\
\hline Water Heater & Gas tankless; EF 0.8+ \\
\hline Other & $30 \%$ reduction in MELs \\
\hline SDHW & Low-cost SDHW \\
\hline PV & $5.5-k W$ dc PV system \\
\hline $\begin{array}{l}\text { Incremental Cost } \\
\text { (relative to code house) }\end{array}$ & \$20/ft ${ }^{2}$ \\
\hline
\end{tabular}




\begin{tabular}{|l|l|}
\hline & Marine, 80\% Savings \\
\hline & Technology Option \\
\hline Walls & $\begin{array}{l}2 \times 6+\text { R-19 cavity+ 2-in. foam sheathing (R-30 } \\
\text { wall assembly) }\end{array}$ \\
\hline Ceiling & R-40 \\
\hline Infiltration & 0.0001 SLA (2 ACH50) \\
\hline Windows: Glass Type & R-10 window, std SHGC (0.3 SHGC) \\
\hline Refrigerator & ENERGY STAR \\
\hline Dishwasher & ENERGY STAR \\
\hline Washer/Dryer & ENERGY STAR \\
\hline Lighting & LED \\
\hline HVAC & AFUE 90+ furnace, SEER 18 A/C \\
\hline Ducts & Tight (mastic, 5\% leakage), in conditioned space \\
\hline Water Heater & Gas tankless hot water, EF 0.8+ \\
\hline Other & $30 \%$ reduction in MELs \\
\hline PV & $3.5-\mathrm{kW}$ dc PV system \\
\hline $\begin{array}{l}\text { Incremental Cost } \\
\text { (relative to code house) }\end{array}$ & \$12/ft ${ }^{2}$ \\
\hline & \\
\hline
\end{tabular}




\begin{tabular}{|l|l|}
\hline & Hot/Humid, 90\% Savings \\
\hline & Technology Option \\
\hline Walls & $\begin{array}{l}2 \times 6+\text { R-19 cavity + 2in. foam sheathing (R-30 } \\
\text { wall assembly) }\end{array}$ \\
\hline Ceiling & R-40 \\
\hline Infiltration & 0.0002 SLA (4 ACH50) \\
\hline Windows: Glass Type & $\begin{array}{l}\text { Low-e/std SHGC glazing, argon fill (0.30 U Value, } \\
0.26 \text { SHGC) }\end{array}$ \\
\hline Refrigerator & ENERGY STAR \\
\hline Dishwasher & ENERGY STAR \\
\hline Washer/Dryer & ENERGY STAR \\
\hline Lighting & LED \\
\hline HVAC & AFUE 90+ furnace, VHP A/C system \\
\hline Ducts & Tight (mastic, 5\% leakage), in conditioned space \\
\hline Water Heater & Gas tankless, EF 0.8+ \\
\hline Other & $30 \%$ reduction in MELs \\
\hline PV & $5.5-k W$ dc PV system \\
\hline $\begin{array}{l}\text { Incremental Cost } \\
\text { (relative to code house) }\end{array}$ & \$15/ft ${ }^{2}$ \\
\hline
\end{tabular}




\begin{tabular}{|l|l|}
\hline & Mixed Humid, 90\% Savings \\
\hline & Technology Option \\
\hline Walls & $\begin{array}{l}2 \times 6+\text { R-21 cavity + 2-in. foam sheathing (R-30 } \\
\text { wall assembly) }\end{array}$ \\
\hline Ceiling & R-40 \\
\hline Foundation & R-10 basement \\
\hline Infiltration & 0.0002 SLA (4 ACH50) \\
\hline Windows: Glass Type & $\begin{array}{l}\text { Low-e/std SHGC glazing, argon fill (0.30 U } \\
\text { Value, 0.26 SHGC) }\end{array}$ \\
\hline Refrigerator & ENERGY STAR \\
\hline Dishwasher & ENERGY STAR \\
\hline Washer/Dryer & ENERGY STAR \\
\hline Lighting & LED \\
\hline HVAC & AFUE 90+ furnace, VHP A/C System \\
\hline Ducts & Tight (mastic, 5\% leakage), in conditioned space \\
\hline Water Heater & Gas tankless, EF 0.8+ \\
\hline Other & $30 \%$ reduction in MELs \\
\hline PV & $4.5-k W$ dc PV system \\
\hline $\begin{array}{l}\text { Incremental Cost } \\
\text { (relative to code house) }\end{array}$ & \$15/ft ${ }^{2}$ \\
\hline
\end{tabular}




\section{Appendix F - \\ Impact of Energy Cost on Consumer Adoption of Zero- Energy Home Technologies}

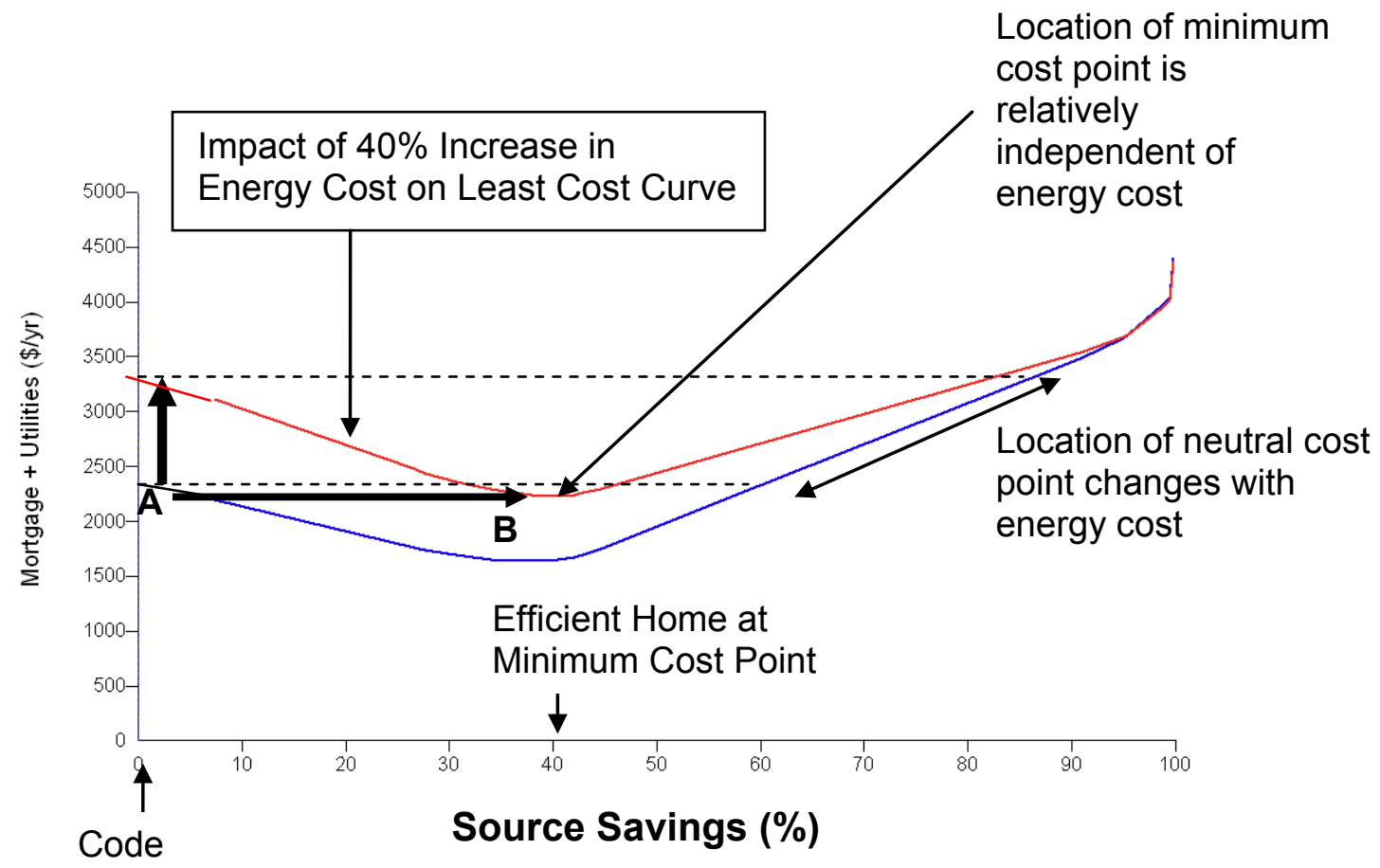

This graph shows that current residential energy codes (point A) do not minimize a homeowner's energy-related costs. Homes built to minimum code also put homeowners at risk when energy costs increase and household incomes are fixed.

In this simple example, energy costs are increased by $40 \%$; all other costs are held constant. Homes with energy savings beyond the minimum cost point (to the right of point B) experience smaller percentage increases in energy-related costs than homes with low energy savings. The change in the location of the neutral cost point is directly proportional to the change in energy cost.

Because of the shape of the least cost curve, large increases in energy cost have very little impact on the location of the minimum cost point. This figure demonstrates that a consumer on a fixed income has a very strong motivation to move from an inefficient code-level home into an efficient home at the minimum cost point when energy costs increase. These results also suggest that the best value and economic security for homeowners would be provided by requiring energy codes to target the minimum cost point. 


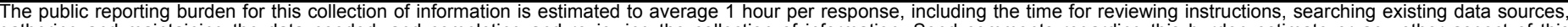

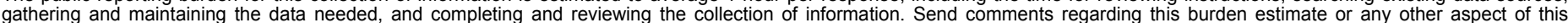

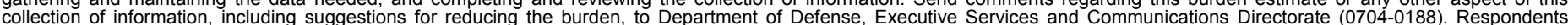

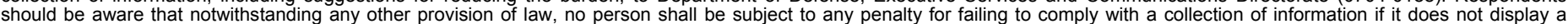

should be aware that notwithstanding

PLEASE DO NOT RETURN YOUR FORM TO THE ABOVE ORGANIZATION.

\begin{tabular}{l|l|l|l} 
1. REPORT DATE $(D D-M M-Y Y Y Y)$ & 2. REPORT TYPE & 3. DATES COVERED (FrOm - TO)
\end{tabular}

November 2008

Technical Report

4. TITLE AND SUBTITLE

Maximizing Residential Energy Savings: Net Zero-Energy Home

Technology Pathways 5a. CONTRACT NUMBER

DE-AC36-08-GO28308

5b. GRANT NUMBER

5c. PROGRAM ELEMENT NUMBER

5d. PROJECT NUMBER

NREL/TP-550-44547

5e. TASK NUMBER

BET98001

5f. WORK UNIT NUMBER
7. PERFORMING ORGANIZATION NAME(S) AND ADDRESS(ES)

National Renewable Energy Laboratory

1617 Cole Blvd.

Golden, CO 80401-3393
8. PERFORMING ORGANIZATION REPORT NUMBER

NREL/TP-550-44547

9. SPONSORING/MONITORING AGENCY NAME(S) AND ADDRESS(ES)

10. SPONSOR/MONITOR'S ACRONYM(S)

NREL

11. SPONSORING/MONITORING AGENCY REPORT NUMBER

12. DISTRIBUTION AVAILABILITY STATEMENT

National Technical Information Service

U.S. Department of Commerce

5285 Port Royal Road

Springfield, VA 22161

13. SUPPLEMENTARY NOTES

14. ABSTRACT (Maximum 200 Words)

To meet current U.S. Department of Energy zero-energy home performance goals, new technologies and solutions must increase whole-house efficiency savings by an additional $40 \%$ relative to those provided by best available components and systems. An expanded research program is needed to develop the key technologies and systems to fill this performance gap. This report identifies a range of technology options to fill the residential efficiency gap in improved systems based on modifications of existing products and high-risk advanced system concepts.

15. SUBJECT TERMS

zero-energy home; zeh; building america

\begin{tabular}{|c|c|c|}
\hline \multicolumn{3}{|c|}{ 16. SECURITY CLASSIFICATION OF: } \\
\hline $\begin{array}{l}\text { a. REPORT } \\
\text { Unclassified }\end{array}$ & $\begin{array}{l}\text { b. ABSTRACT } \\
\text { Unclassified }\end{array}$ & $\begin{array}{l}\text { c. THIS PAGE } \\
\text { Unclassified }\end{array}$ \\
\hline
\end{tabular}

\begin{tabular}{l|l|} 
17. & LIMITATION \\
OF ABSTRACT & $\begin{array}{l}\text { 18. } \\
\text { NUMBER } \\
\text { OF PAGES } \\
\text { UL }\end{array}$ \\
\end{tabular}

19a. NAME OF RESPONSIBLE PERSON

19b. TELEPHONE NUMBER (Include area code) 